\title{
CHILDISHNESS, PRIMITIVISM AND THE PRIMITIVE AS CHILD IN THE ANTI- IMPERIALIST WORKS OF ROBERT LOUIS STEVENSON
}

\author{
By
}

Thomas Bogle Petterson

A thesis submitted to the Victoria University of Wellington in fulfilment of the requirements for the degree of Master of Arts in English Literature

Victoria University of Wellington 


\begin{abstract}
My thesis examines the connection between childishness and primitivism in four key works by Robert Louis Stevenson: Kidnapped, "The Beach of Falesá", The Ebb-Tide and A Footnote to History: Eight Years of Trouble in Samoa. In particular, I discuss Stevenson's depiction of "primitive" peoples - the Scottish Highlanders of Kidnapped and the Pacific Islanders in the other works - as childish or childlike. While this is a trope that was typically used to justify imperial domination by "adult" Europeans (by writers such as H. Rider Haggard and Rudyard Kipling, for instance), for Stevenson the case is somewhat different because of the extent to which he valorises childishness. The "Introduction" places Stevenson's anti-imperialist deployment of the primitive-as-child trope in the context of romanticism and primitivism more generally, trends which idealised children and primitives in response to the degrading forces of industrial capitalist development in Europe. The first chapter shows how Stevenson's idealised notion of childish Highlanders in Kidnapped is used to valorise them at the expense of the sedentary and conformist "adult" world of the Lowlands. In the second chapter, I show how Stevenson similarly valorises the childish native characters in "The Beach of Falesá" and The Ebb-Tide, while at the same time he dismantles the notion that European colonisers of the Pacific possess any "adult" authority whatsoever by depicting the latter as being in the grip of infantile delusions. In these late fictional works, the idealised childishness of the natives, characterised by growth and vitality, is contrasted with European infantilism, which signifies the cultural regression and insularity that Stevenson saw as closely connected with imperial activity. My final chapter shows how these two opposed notions of childishness-as-growth and childishness-as-decay/insularity inform Stevenson's nonfiction anti-imperialist work, A Footnote to History. My thesis aims to show that Stevenson was not so constrained by imperialist clichés and rhetoric as some critics have argued; rather, I suggest that his sympathy for the victims of colonisation allowed him to dramatically undermine this rhetoric.
\end{abstract}




\section{CONTENTS}

$\underline{\text { Introduction }}$

"Honourable toil" in Childhood and in "the childhood of the race" $\ldots \ldots \ldots \ldots \ldots 4$

\section{Chapter 1}

An Uneasy Journey Toward Adulthood and Civilisation: Childish Highlanders and

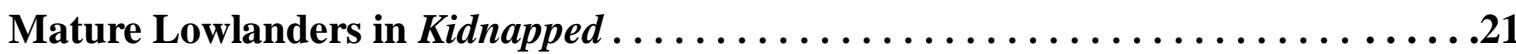

\section{Chapter 2}

Infantilisation in "The Beach of Falesá" and The Ebb-Tide .............. 38

- "The Beach of Falesá": Going Native as Growing Up . . . . . . . . . 44

- The Infantile Insularity of Imperialism in The Ebb-Tide ... . . . . . 60

\section{Chapter 3}

A Footnote to History: Native Schoolboys and Foreign Bullies in Samoa ........ 73

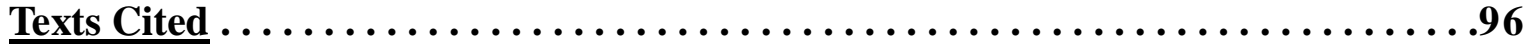




\section{Introduction}

\section{"Honourable toil" in Childhood and in "the childhood of the race"}

From a very early stage in his career, Robert Louis Stevenson was drawn to writing about children and childishness. G. K. Chesterton, writing in 1927, identified the notion that "we should learn morality from little boys" (94) as central to Stevenson's work, to the exclusion of other concerns: "he did not try to construct an optimist philosophy like Spinoza or Emerson; he did not preach a good time coming like William Morris or Wells; he did not appeal to Imperialism or Socialism or Scotland: he appealed to Skelt" (93) (i.e. to Skelt's juvenile theatre, which Chesterton sees as emblematic of Stevenson's childhood). But Stevenson's interest in childhood is not so abstractly and narrowly moral, so divorced from wider social concerns, as Chesterton implies.

From Stevenson's earliest writings children and childish characters are associated with "primitive" or "savage" peoples - the inhabitants of what Rousseau calls "the youth of the world" (Discourse 65). Conversely, when Stevenson wrote of people who were generally considered "savages" - namely, eighteenth-century Scottish Highlanders and, later, contemporary Pacific Islanders - he portrayed them as childish or childlike. Comparing primitives (or natives or "savages") to children is, as we shall see, a familiar trope in imperialist writing, and Stevenson's use of it has been explained as a sign of his being "subject to the prejudices of his time" (Linehan 362; see also Saposnik 87). In this thesis, however, I will argue that Stevenson uses the trope not to justify subjecting natives to colonial rule but, on the contrary, to portray colonial officials as ignorant outsiders, with no inherent right to impose their will. Although it is often argued that Stevenson's Pacific works represent a substantial departure from "the kinds of romances and fantasies with which he had won his fame" (Jolly, "Introduction" xxix; see also Jackson 31, Bristow 123 
and Thorburn 25), Stevenson's comparisons between children and primitives demonstrate a basic continuity in his outlook. Julia Reid notes that "an interest in the 'primitive' forms a unifying preoccupation across [Stevenson's] work" (5), and it is in the context of this primitivism that we must examine his use of the child/savage trope. As this thesis will show, Stevenson's primitivist deployment of the trope, from his early work onward, enabled him to produce trenchant critiques of imperialism in the South Pacific. The imperious and aloof adults in (for instance) Treasure Island share a similar narrowmindedness and blindness to the colonial officials in A Footnote to History and the emissaries of British "civilization" in Kidnapped and Catriona. Children and natives, by contrast, are generally depicted as heroic and insightful. Stevenson's conception of children as "savages" is a romantic-primitivist one which expresses his partisanship for both, and an ambivalent attitude - at times a veiled antipathy, at times outright hostility toward the degrading forces of adult and "civilized" society.

This attitude can be found in Stevenson's earliest works. His short sketch, "Notes on the Movements of Young Children" (1874), for instance, published when he was just 23, might appear merely "whimsical" (Rosen 54): it records his observations of young French girls dancing and at play and attempts to draw out the "many reasons why [the] gracelessness of young children should be pretty and sympathetic to us" (Stevenson, "Notes" 199); a young child's movements are like those of a "tight-rope walker [who] does not walk so freely or so well as any one can walk upon a good road; and yet we like to watch him for the mere sake of the difficulty" (200). But in praising the girls' nonconformity and their relative immunity to criticism Stevenson also reveals his hostility toward the adult onlookers: the young dancer "was not to be daunted by any merriment of people looking on critically; the music said something to her, and her whole spirit was intent on what that music said" (197-8). Stevenson adds that the "secure and accomplished movements of persons more fully grown" (200) are not nearly as interesting to watch, 
because

the child tries to dance for its own pleasure, and not for any by-end of ostentation and conformity. If we did not know it we should see it. There is a sincerity, a directness, an impulsive truth, about their free gestures that shows throughout all imperfection, and it is to us as a reminiscence of primitive festivals and the Golden Age. (200)

In "Notes" the "gracelessness" of children is depicted as more interesting - indeed, more graceful - than "secure and accomplished" adult movement, because children must put in more effort, more "honourable toil" (199-200) than adults. ${ }^{1}$ Paradoxically, in order to do this and thereby to learn and progress, the child must escape the modern, adult world and return to a previous "Golden Age". Much later, in A Footnote to History, Stevenson would project these childish qualities onto native Samoans, and would contrast the German imperialists' mechanical bombardment of villages from their battleships with a more honourable, less "secure and accomplished", more childish Samoan form of warfare.

Michael Rosen describes Stevenson's comparison of children to primitives as "the conventional and idealized view of the time" (54). Certainly, the child-as-primitive analogy had become axiomatic by the 1870 s, but to call Stevenson's use of it simply "conventional" is to obscure the very different meanings which the trope could be used to express. Thomas Arnold, the headmaster of Rugby School and one of the pioneers of public school education, used it in order to emphasise his pupils' innate sinfulness:

From the natural imperfect state of boyhood, they are not susceptible of Christian principles in their full development upon their practice, and I suspect a low standard of morality in many respects must be tolerated

1 This view is less unwarrantedly nostalgic or "idealized" than it first appears: Lucy Rollin suggests that Stevenson's view of childhood reflects the fact that "[h] uman beings experience a literal loss of neurological capacity as they leave childhood. [. . . ] Half our ability to respond to stimuli disappears by puberty" (73). There are echoes of Stevenson's view in those of the radical education theorist John Holt, who argues that by the time a child reaches school-age he has "[a]lready, by paying close attention to and interacting with the world around him, and without any school-type formal instruction, [. . .] done a task far more difficult, complicated and abstract than anything he will be asked to do in school or than any of his teachers has done in years. He has solved the mystery of language" (23). 
amongst them, as it was on a larger scale in what I consider the boyhood of the human race. (91)

To turn boys into men, which Arnold saw as his duty, was comparable to civilizing colonial subjects. Arnold's primitive pupils are almost the exact opposite to Stevenson's primitive young dancers: for Arnold, "the boyhood of the human race" is not a source of purity or truth, but a source of sin. To understand how the same trope could be used for such different purposes - how it could, on the one hand, be used to promote both imperialism and disciplinarian education while, on the other hand, it could be deployed against these enterprises - we need to briefly examine its history.

In turning to this, I must first deal with an argument recently put forward by Bill Ashcroft, a prominent figure in the field of post-colonial criticism, ${ }^{2}$ which presents a direct challenge to my contention that comparisons between children and primitives (or "savages" or natives) could ever be anything other than pro-imperialist in their connotations. According to Ashcroft, the savage-as-child was one of a number of "tropes which invariably justified colonial rule, no matter how benign it saw itself to be" (my emphasis). This is because it offered "a unique tool for managing the profound ambivalence of imperialism, because it absorbed and suppressed the contradictions of imperialist discourse itself" (36):

As a child [Ashcroft writes], the colonial subject is both inherently evil and potentially good, thus submerging the moral conflict of colonial occupation and locating in the child of empire a naturalization of the 'parent's' own contradictory impulses for exploitation and nurture. The child, at once both other and same, holds in balance the contradictory tendencies of imperialist rhetoric: authority is held in balance with nurture; domination with enlightenment; debasement with idealization; negation with affirmation;

2 Ashcroft is not the only recent literary theorist/critic to analyse the trope (see also Jacqueline Rose). He is, however, the first to give a thorough analysis in terms of postcolonial theory (as opposed to theories about childhood or children's literature). 
One of the problems for this view is that it does not account for writers, including Stevenson, for whom children were not "inherently evil and potentially good". Ashcroft, it should be noted, contradicts himself on this score when he acknowledges the influence on nineteenth-century thought of Jean-Jacques Rousseau's idea of childhood as a state of innocence (41) - but more on this presently. ${ }^{3}$ Even granting the claim (which Ashcroft unfortunately does not attempt to substantiate) that Victorian parents possessed "contradictory impulses for exploitation and nurture", it remains unclear just how these are "submerg[ed]" or "naturaliz[ed]" or held in "balance" either in the sphere of parenthood or when they are "locat[ed] in the child of empire". David Grylls argues that conflicting ideas about childhood and the role of parents were very much out in the open during the nineteenth-century, and by mid-century the Puritan view had been "grievously undermined" (37). The popularity of writers concerned with the rights of children, including Charles Dickens, would seem to confirm this.

There is a further problem related to Ashcroft's assertion that a given trope can "invariably" carry with it a justification for colonial rule, regardless of the particular context - historical, cultural and biographical - in which it is used. This view of language is typical of much post-colonial theory, dating back to Edward Said's influential discussion of Orientalist discourse, which Ashcroft takes as the "useful model" for his own analysis (36). In Said's Orientalism, the impetus for imperialism emerges not as primarily economic, but rather as the product of Western antipathy toward "the Orient" dating back

3 Ashcroft also allows that a "post-colonial" writer like David Malouf is able to "reshape[... .] the trope into a vision of post-colonial possibility" (3). Part of the problem with his argument seems to stem from the desire to draw a clear distinction between colonial and "post-colonial" literature while at the same time refusing to clearly define the term "post-colonial". For instance, he writes that "post-colonial analysis [. . .] examines the full range of responses to colonialism, from absolute complicity to violent rebellion. There is no post-colonial discourse which is not complicit in some way, and extremely little which is not oppositional, but all of it is about change in some form or other". Ashcroft further qualifies this definition (if that is the right word) by stressing that "the post-colonial [ . . is] the discourse of the colonized" (19), but this seems to me an entirely arbitrary distinction. Surely Ashcroft would agree that there were in fact plenty of nineteenth century European writers who responded to colonialism, with varying degrees of complicity and opposition. (Stevenson's Pacific fiction, incidentally, has been described as "postcolonial" (Jolly, "The Ebb-Tide and The Coral Island" 79)). 
to the time of Dante and even to ancient Greece, which gradually and inexorably "transformed itself from being textual and contemplative into being administrative, economic, and even military" (210). For Said, Orientalist discourse cannot be seen as a mere "rationalization of colonial rule" because of "the extent to which colonial rule was justified in advance by Orientalism, rather than after the fact" (39); or, as he puts it elsewhere in the book:

the very designation of something as Oriental involved an already pronounced evaluative judgement, and in the case of peoples inhabiting the decayed Ottoman Empire, an implicit program of action. Since the Oriental was the member of a subject race, he had to be subjected: it was that simple.

Since he conceives of imperialism as merely the administrative, economic and military form assumed by racist ideology, Said is also committed to the view "that every European, in what he could say about the Orient, was consequently a racist, an imperialist, and almost totally ethnocentric" (204). Ashcroft expresses much the same view when he quotes Heidegger: "Language speaks. Man only speaks insofar as he complies with language" (108). Europeans, for Said and Ashcroft, are imprisoned by the language available to them, which contains an invariably racist, imperialist logic. From this position, Said argues that even Karl Marx is forced to express imperialist, racist views seemingly in spite of his sympathy for colonial subjects: "he confronted a more formidable censor in the very vocabulary he found himself forced to employ" (155). Similarly, when Ashcroft notes, in passing and without comment, Marx's use of the child-as-primitive trope (37-38), the implication is clear: since the trope "invariably justified colonial rule", Marx's use of it must be imperialist too. ${ }^{4}$

4 It is worth considering the political conclusions Ashcroft derives from his view of the censorial power of language or discourse. Although he writes that "[t]he sovereignty of discourse [...] must be balanced against the agency of the subject which it purportedly constructs" (103), the form that "post-colonial" political resistance can take is always, for Ashcroft, strictly limited. "Transformation", he writes, "is 
Aijaz Ahmad has challenged Said's approach, arguing that "he detaches a certain passage from its context, inserts it into the Orientalist archive and moves in different, even contradictory directions" (223). Ahmad asks:

[I]f particular representations and discursive statements - if in fact they are discursive statements - can float so easily in and out of various discourses [e.g. the discourses of Marxism and Orientalism], then in what sense can we designate any one of them a discourse in which the whole history of Western enunciations is so irretrievably trapped? (230-31)

This criticism could apply just as much to Ashcroft's analysis of the child-as-savage trope as to Said's conception of Orientalism. The claims of Rosen, Linehan and other critics that Stevenson's use of the trope is merely "conventional" Victorian prejudice fall into the same trap of assuming that such statements carry the same meaning wherever they are used.

Having said all this, it should be emphasised that in the majority of its latenineteenth century manifestations the child/savage analogy did carry a thoroughly reactionary message, whether its target was children or colonial subjects. This was not due to any rigid, hierarchical logic inherent in the trope itself, but rather to concrete, identifiable historical developments. Hugh Cunningham, for instance, notes that representations of English street children as savages became increasingly common during the late 1840s and 1850s (123) and argues that this was due to increased anxiety about their "large numbers", combined with "the longstanding worry about the idleness of children" (97); the requirement for child labourers in the wake of the Industrial Revolution was also a factor, as various statements of politicians make clear (103). The comparison

achieved in many ways, but it always results from the interpolation of the dominant discourse" by exploiting its "[h]airline fractures" (112). Ashcroft is often exasperatingly vague, but he clearly sees systematic political resistance as impossible: "The resistance of the post-colonial is better defined by what de Certeau refers to as 'tactics' rather than 'strategies' [ . . . 'a tactic is an art of the weak' [ . . ;] indeed, you cannot have a formal tactics, only an ensemble of which particular tactics are deployed for specific purposes" (ibid). 
could also apply to the children of the upper and middle classes, as we have seen in the case of Arnold, with the purpose of instilling obedience by treating children as lesser beings that needed civilising.

In the 1860 s, the child-as-savage analogy "worked its way up to become a key part of the thinking of natural and social scientists" (123) - Enrst Haekel's theory that ontogeny recapitulates phylogeny (i.e. that different races represented different stages of individual human development) was formulated in 1866 - with implications for both children and colonial subjects which were "hardly reassuring" (125). Stephen Jay Gould sums up the implications for imperial policy:

If adults of lower races are like white children, then they may be treated as such - subdued, disciplined, and managed (or, in the paternalistic tradition, educated but equally subdued). The "primitive-as-child" argument stood second to none in the arsenal of racist arguments supplied by science to justify slavery and imperialism. (126)

In literature, this attitude manifests itself perhaps most notoriously in the works of such writers as Rudyard Kipling and H. Rider Haggard. The latter, in King Solomon's Mines, has Ignosi declare to Allan Quatermain that he is "but a child in wisdom beside thee" (168), and therefore unfit to give the white men orders despite being heir to the throne of Kukuanaland. As Ashcroft observes of Allan Quatermain, Haggard's portrayal of a childlike native society is an idealized one, but this merely makes it "the perfect surface for the inscription of imperial adventure and maturity" (40). Kipling is perhaps a more interesting case, for the British boy-heroes of Kim and stories like "Tods' Amendment" are distinguished by their ability to "go native". Tods, for instance, is described favourably as "an utterly fearless young Pagan" (144) who is "precocious for his age", having learnt "some of the more bitter truths of life" by "mixing with the natives" (145). The epigraph to "Tods' Amendment" reads: "God's mercy is upon the young / God's wisdom in the baby 
tongue / That fears not anything" (144). But while he depicts the European child-as-native as heroic, Kipling does not extend this heroism to childlike natives, who are rather "Halfdevil and half-child" ("White Man's Burden").

The analogy gained more scientific credibility as the century progressed and as the imperial powers spread across the globe. In 1895, the year after Stevenson's death, Herbert Spencer wrote that "[t]he intellectual traits of the uncivilized, [. . . ] are traits recurring in the children of the civilized" (quoted in Gould 128). George Boas notes, "[a]s late as 1911 we find in Hastings's Encyclopaedia of Religion and Ethics the sentence, 'The "childhood of the race", originally a metaphor, has become an almost technical term, through the establishment of the law of recapitulation"” (65). And after its scientific formulation was discredited in the 1920s, the "social and psychological applications" of the analogy lingered well into the twentieth century (ibid). In the 1950s, Aimé Césaire identified the trope in the work of psychoanalyst Octave Mannoni, who wrote that a Madagascan was unable "to break the bonds of dependency, to become the equal of his father" (quoted in Césaire 40). Césaire wrote: "Don’t let the subtleties of vocabulary, the new terminology, frighten you! You know the old refrain: 'The-Negroes-are-big-children.' They take it, they dress it up for you, tangle it up for you. The result is Mannoni” (ibid). The analogy was still, at this time, very much a part of conventional racism. In Black Skin, White Masks, Frantz Fanon observes that "[a] white man talking to a person of color behaves exactly like a grown-up with a kid, simpering, murmuring, fussing and coddling” (14).

Without disputing any of this, I intend to show that to read such attitudes into Stevenson's works is problematic. Stevenson read Spencer and Darwin, and was almost certainly aware of the scientific formulation of the child-as-primitive. But the equation was not used to rationalize imperialist conquest. Ashcroft groups Stevenson with Kipling and Haggard, and claims that all three responded to the "decay produced by the Industrial Revolution" by producing "imperial adventures" which were motivated by "the desire for 
moral, physical and racial renewal". "Overseas colonies," he writes, "could be the means of regenerating the English race" by restoring it to a youthful and vigorous state (41). Jacqueline Rose similarly argues that adventure stories "about the primitive and the child (the primitive as child)" rested on "a belief in childhood as something which is able to bypass the imperfections of the civilised world" and thus "resolve a fundamental contradiction - that of seeing modern society as degenerate while still wishing to preserve its superiority over an otherwise idealised primitive state" (53). This may indeed be one of the motivations behind some imperial adventure-romances. Arguably, Haggard and Kipling responded to the "decay" of European civilisation with works which, in a sense, "bypass[ed]" it or suggested that it could be straight-forwardly "renew[ed]", thereby buttressing (or at least leaving intact) the ideology of imperialism. But there is no reason to suppose that this is true of the romance genre in general, or of Stevenson's works in particular. For Stevenson, imperial adventure could not resolve the contradiction "of seeing modern society as degenerate while still wishing to preserve its superiority over an otherwise idealised primitive state" because it was precisely in imperial conquest that the degeneracy of modern society was most clearly on display. His works (including, I will argue, not just those of his later period but also romances like Kidnapped and Treasure Island) use the figure of the child and the primitive as child in order to draw attention to the contradictions (hypocrisy is perhaps a better word) of modern society - not to resolve or by-pass them. He transferred to the victims of imperialism his empathy for children as the victims of disciplinarian adults. For Stevenson, children are subject to the whims of "unthinkable deities" who behave, from the child's point of view, in an utterly irrational manner: "who profess the tenderest solicitude for children, and yet every now and again reach down out of their altitude and terribly vindicate the prerogatives of age" ("Child's Play" 131). As we shall see, Stevenson depicts the behaviour of colonial agents in the 
Pacific as similarly hypocritical..$^{5}$

Stevenson's use of the child/savage analogy to attack modern society has something in common with romantic ideas dating back to Jean-Jacques Rousseau. His plea in "Child's Play" for adults to "leave [children] in their native cloud-land, where they figure so prettily - pretty like flowers and innocent like dogs" (133) echoes Rousseau's analogy between the child and a "young tree" which must be protected from "the crushing force of social conventions" but whose natural growth must otherwise not be interfered with (Emile 5-6). Rousseau's philosophy of child-rearing was inseparable from his vision of society in its "happiest and most durable epoch", described in Discourse on the Origin of Inequality as

a middle position between the indolence of our primitive state and the petulant activity of our egocentrism[. . . . The example of savages, almost all of whom have been found in this state, seems to confirm that the human race had been made to remain in it always; that this state is the veritable youth of the world; and that all the subsequent progress has been in appearance so many steps toward the perfection of the individual, and in fact toward the decay of the species. (my emphasis 65)

Rousseau's influence on nineteenth-century views of childhood has been widely acknowledged. Grylls argues that "Victorian responses to children were the product of two quite different intellectual traditions. One was broadly the legacy of Rousseau; the other of John Wesley” (23). Boas and Isaiah Berlin see Rousseau as an anti-intellectual (Boas 76; Berlin 41) and there is no shortage of evidence to back this up: the virtue of the savage, for Rousseau, is that, "for lack of wisdom and reason he is always seen thoughtlessly giving in to the first sentiment of humanity" (Discourse 55). Too much knowledge thwarts such natural sentiments, leading to "the decay of the species". But Rousseau does not reject

5 Indeed, Stevenson seems to have been aware of the tendency to idealize natives simply in order to justify their exploitation: in A Footnote to History he conceives of Samoans as "a gentle race, gentler than any in Europe", but adds that "we are often reminded of the circumstance, not always by their friends" (70). 
Bogle Petterson 15 knowledge altogether: his emphasis is on balance, on the need to ensure that knowledge springs from nature, rather than being imposed upon it. As Peter Gay argues, "Rousseau directed his energy toward discovering not a state of nature without culture but a culture that would realize man's true nature" (95). Such a philosophy of "negative education" was a direct challenge to the authority of adults generally and in particular to the Puritan notion that children must receive religious indoctrination from a young age: for Rousseau, children would learn best by having their natural curiosity satisfied, rather than by attempts to mould them out of shape.

Rousseau's view is implicitly anti-colonial. Some measure of adult interference in a child's life is inevitable: the child, after all, "is no savage to be banished to the desert, he is a savage who has to live in the town. He must know how to get his living in a town, how to use its inhabitants, and how to live among them, if not of them" (Emile 167). But for a decayed society to intrude into the "youth of the world" would be an unjustifiable violation of the laws of nature, since "the human race had been made to remain in [this state] always". Ashcroft seems to miss this crucial distinction when he claims that Rousseau's view "justified the paternal actions of imperial formation" by depriving children and colonial subjects of any "access to meaning outside the processes of civilisation and education which bring them into being, even when that meaning is one of an idyllic preformed, pre-industrial innocence" (41). The savage, for Rousseau, does not require any paternal assistance in order to remain in a state of innocence.

This anti-colonialism is more explicit in the work of Rousseau's friend, Denis Diderot (not mentioned by Ashcroft), whose Supplément au Voyage de Bougainville, a dialogue inspired by Bougainville's account of his stay in Tahiti, contains the following exchange:

$\mathrm{A}-[\ldots]$ But in a word, tell me: Is it better to civilise man or to allow him to follow his instinct? 
$[\ldots]$

B - If you propose to be his tyrant, civilise him; poison him as best you can with a morality contrary to nature. [. . .] Or would you rather he be happy and free? Then don't meddle in his affairs[.] (72)

The Supplément contrasts an idealised picture of life in a Tahitian village with the hypocritical morality of Christian Europe. In Diderot's work we find none of Rousseau's ambiguous anti-intellectualism. Nature and knowledge are not opposed: rather, for Diderot's Tahitian speaker, Orou, the "strange precepts" of European morality are both "contrary to Nature [and] an offence against reason" (50). Another old Tahitian man tells Bougainville and his crew: "Leave us to our ways; they are wiser and more decent than yours. We have no wish to exchange what you call our ignorance for your useless knowledge" (43); according to "B", the Tahitians are "wise" precisely because they "have stopped their development at an early stage" (66). Echoing Rousseau, "B" explains that Tahitians are a younger race than Europeans: "The Tahitian is close to the origins of the world and the European near its old age. The gulf between us is greater than the new-born child from the decrepit dotard" (40).

Diderot's childish Tahitians are a sharp contrast to Haggard's childish Kukuanas. For Haggard, to be a "child in wisdom" is to lack wisdom, whereas for Diderot the childish races are wiser by virtue of their childishness, for to advance beyond a youthful stage is to become "decrepit", to bury natural wisdom under a heap of "useless knowledge". Conversely, the child as savage becomes wiser than the adult: in Wordsworth's famous line, "The Child is father of the Man" (7). Matei Calinescu observes that the "parallelism between the life of mankind and that of a human individual had a long tradition", dating back to Saint Augustine (26). For a philosopher like Francis Bacon, this parallelism implied a stable sense of historical progress: modern Europe was the most highly advanced 
society in the world, both in age and wisdom. ${ }^{6}$ But Calinescu also identifies a different, more ambiguous conception of progress, according to which modern society may be "more advanced [than primitive society ...] in absolute terms, by virtue of the cumulative effect of learning, but in relative terms [the moderns'] own contribution to learning is so small that they may justly be compared to pygmies" (16). This conception emerged in the twelfth century and was frequently expressed in "the famous maxim about the dwarf standing on the shoulders of a giant and being thus able to see farther than the giant himself" (15). As John of Salisbury put it: "we see more and farther than our predecessors, not because we have keener vision or greater height, but because we are lifted up and borne aloft on their gigantic stature" (quoted in ibid). Michel de Montaigne makes the same point and notes that "he who has mounted highest has often more honour than he deserves, for on the shoulders of the last but one he is only one barleycorn higher" (quoted in Calinescu 16-17). Calinescu suggests that, "[s]een from this vantage point, progress and decadence appear to be intimately linked: the men of a new age are more advanced but at the same time less deserving than their predecessors" (16). The youthful races have put in more "honourable toil", to use Stevenson's phrase. Diderot and Rousseau take this paradox even further: past a certain point, the very accumulation of knowledge becomes an unwise endeavour, and to age is no longer to mature, but to "decay", undoing past achievements. For these philosophers, the dwarf sees no further than the giant, for having mounted upon his shoulders, he causes the giant to stoop.

This paradox, according to which society degenerates as it seems to move forward, had a heightened resonance for writers in the age of the Industrial Revolution and the imperialist expansion it brought with it. Capitalist property relations, as Lenin later wrote,

6 Bacon writes: "And truly as we look for greater knowledge of human things and a riper judgement in the old man than in the young, because of his experience and the number and variety of things which he has seen and heard and thought of; so in like manner from our age, if we but knew its own strength and chose to essay and exert it, much more might fairly be expected than from the ancient times, inasmuch as it is a more advanced age of the world, and stored and stocked with infinite experiments and observation" (quoted in Calinescu 25). 
Bogle Petterson 18 had outlived their progressive phase and were now comparable to "a shell which no longer fits its contents, a shell which must inevitably decay if its removal is artificially delayed" (my emphasis 120). This sense of decay (if not necessarily of its economic roots) was widely felt, and writers responded in different ways, depending on a number of factors, including their political orientation. In this context, Peter Coveney argues, many writers were attracted to the image of the child as a "symbol of Imagination and Sensibility, a symbol of Nature set against the forces abroad in society actively de-naturing humanity" (31). Oscar Wilde, for example, saw childhood as symbolic of a more harmonious social order: under socialism, he argued, "[t]he personality of man [. . . will be as wonderful as the personality of a child" (134). However, at the same time as some authors used childhood as a means of social critique, for others it became "an habitual means of escape, a way of withdrawing from spiritual and emotional confusion in a tired culture" (Coveney 32).

The primitivist movement in art emerged at the same time as the increased focus on childhood as another response to industrialization. Just as the "[i]dealization of the child's nature and cruelty towards the 'children of Satan' existed side-by-side in nineteenthcentury society" (34) so too did the idealization of primitive cultures and the brutal, racist suppression of those cultures. By the middle of the nineteenth century, Calinescu argues, "two distinct and bitterly conflicting modernities" had emerged: on the one hand, a triumphalist "bourgeois idea of modernity", which upheld a "doctrine of progress"; on the other hand, a bitterly opposed aesthetic or cultural modernity, defined primarily by "its outright rejection of bourgeois modernity, its consuming negative passion" (41-42). The different uses of the child-as-savage or child-as-primitive trope fall into one or other of these categories, or somewhere in between: on the one hand, it could be used to justify Europe's subjugation of other races and to defend the mistreatment of children; but it could also be used to express misgivings about imperialism and about disciplinarian attitudes 
toward children - and about modern society in general.

Ralph Waldo Emerson, for instance, used the primitive child to attack what he saw as mechanical and impersonal modernity. He conceived of modern man as shrunken - "a god in ruins", "the dwarf of himself" - and argued that children could help check the further degeneration of society and even restore humanity to its former glory and wisdom: "Infancy is the perpetual Messiah, which comes into the arms of fallen men, and pleads them to return to paradise" ("Nature" 47). This draws a clear parallel between infancy and the infancy of the race, and suggests that the latter resides in the former. In "Self-Reliance" Emerson contrasts the vitality of "savage" life with slothful modernity and seems to suggest that the fallen world might look to the youthful one for salvation or regeneration:

[T]he white man has lost his aboriginal strength. [. . .] The civilized man has built a coach, but has lost the use of his feet. He is supported on crutches, but lacks so much support of muscle. [. . .] [I]t may be a question whether machinery does not encumber; whether we have not lost by refinement some energy, by a Christianity, entrenched in establishments and forms, some vigor of wild virtue. (161-62)

Just as the grown man can be saved by the child, "civilized" society can learn from or be renewed by "savage" society. There is no reason to believe that this view is straightforwardly conservative: for Emerson, a return to an ideal society required abolishing slavery and ending expansionist wars.

The works examined in this thesis reveal a much more complex engagement with the trope. In Stevenson's "Notes", a child learns to dance by eschewing the unhelpful ridicule of "accomplished" adults and instead recapitulating "primitive festivals". Growth, for Stevenson, does not signify merely renewal in Rose and Ashcroft's sense of the word, but rather opposition to the puritanical and detached adult world. Likewise, Stevenson portrays native societies as childish not in order to re-invigorate or legitimize, but in order 
to oppose imperialism. While works like Kidnapped and A Footnote to History associate primitive and childish societies with growth and vitality, Stevenson conversely portrays civilised, imperial societies as degenerate and dwarfed. As we shall see, this sense of degeneracy at times leads Stevenson to portray imperialism itself as a reversion to infancy, exposing it as an enterprise entirely lacking in "adult" authority. In Footnote, Stevenson holds the European colonial administrators responsible for what he calls the "progressive decivilisation" of Apia (82), and depicts their various manoeuvres and machinations as childishly insular and erratic. In Stevenson's Pacific works, the child-as-savage trope is thus inverted and takes on another meaning; childishness as a state of growth and vitality, when applied to primitive societies, sits alongside, and is contrasted to, childishness as a stage of decay, bound up with imperial barbarism. 


\section{Chapter 1}

\section{An Uneasy Journey Toward Adulthood and Civilisation: Childish Highlanders and Mature Lowlanders in Kidnapped}

On its surface, Kidnapped tells the story of David Balfour's quest for his inheritance, his journey towards the city, employment, respectability and adulthood. This progression is interrupted and disrupted, however, by the kidnapping itself and by David's subsequent adventures in the Highlands. This is not simply a detour on the road to prosperity. As he is thrown into the Highlands, away from the urban, capitalist centre and into an undeveloped land populated by childish primitives, David's ultimate goal - adulthood - does not simply recede into the distance. Rather, the values that this status appears to represent are drastically undermined. David's travels and adventures are not in the nature of rituals or trials through which he can straight-forwardly advance towards or "earn" the status of adulthood. The chief symbol of adulthood in Kidnapped is David's inheritance, and the unease he feels at the end of the novel derives, I would suggest, partly from the fact that he has not really earned this wealth. Stevenson's childlike, primitive Highland society is not "the perfect surface for the inscription of imperial adventure and maturity", as Bill Ashcroft describes the primitive country in Haggard's Allan Quartermain (40). On the contrary, if rites of passage are a convention of boyhood romances then they are a convention which Kidnapped subverts, for with each act of bravery David risks moving further away from maturity and empire. He attempts to resist this movement by disowning his acts; as Julia Reid notes, David "dislikes rebellion against authority" (129). Nonetheless, as a land of youthful, improvised adventure, freedom and self-direction, the Highlands profoundly unsettle the "precociously mature" (Eigner 91) David's received 
notions of adult respectability.

Adulthood does not emerge naturally out of David's adventures but is instead tacked on, received or inherited. This is reflected in the novel's structure. In response to one reviewer, Stevenson agreed that Kidnapped had "two parts": "I began it partly as a lark, partly as a pot-boiler; and suddenly it moved, David and Alan stepped out from the canvas, and I found I was in another world". The beginning and ending - that is, the parts dealing directly with David's quest for his inheritance and set in the Lowlands - were “merely galvanised: no work, only an essay" (qtd. in Maixner 246). As Oliver S. Buckton puts it, "the journey in Kidnapped exists in an uneasy relation to the novel's plot, tending to disturb and divert its course toward closure" (143). Stevenson saw this as a defect, but the power of the novel derives precisely from the juxtaposition of its "two parts" - the scripted, imposed frame or plot and the disruptive, improvised, childish journey - and the disruptive effect of the latter upon the former. The "galvanised" part of the novel deals with David's entry into adult society, which also suggests the "maturation" of Scotland: the defeat of the Jacobites signalled the end of the pre-industrial era. Yet, as Reid perceives, this "passage to modern, commercial life is [. . .] evoked as a loss rather than a triumph" (130). Stephen Shapiro similarly argues that the novel should be read "as an investigation into the violent process by which the new is wrenched out of the old" (133). This is reflected in David's own sense of loss at the end of the novel - the "cold, gnawing in [his] inside like a remorse for something gone wrong" ( $K$ 219). At the same time, the appeal of adulthood for David is, paradoxically, the security and dependence that it offers. To enter the adult, "civilised" world, far from assuming greater personal autonomy, David must surrender to a conventional script - quite literally, to a part that has been written for him, both in the letter of the law and also, mechanically and conventionally "galvanised" by Stevenson himself.

Adulthood thus also stands for the colonial incursion into the Highlands, which 
Kidnapped and its sequel Catriona depict as a blind, mechanical force, beyond the control of any individual - a loss of agency itself. In the latter novel, David arrives at the bitter conclusion that resistance is a youthful (and essentially futile) affair: "till the end of time young folk (who are not yet used to the duplicity of life and men) will struggle as I did, and make heroical resolves, and take long risks; and the course of events will push them upon the one side and go on like a marching army" (187). Maturity is linked to both militarism and narrative conformity (following "the course of events"): to become an adult, at least in the Lowlands, is to get "used to the duplicity of life and men", to be domesticated, to shed one's individuality and become part of the "marching army". By opposing this army, Stevenson's childish, primitive Highlanders serve to expose the scripted and conformist nature of adult, civilised society, and to subvert its presumed supremacy.

The link between militarism and maturity is implicit from the start of Kidnapped: David's attraction to adult civilisation is reflected in his admiration for the British "redcoats". He first sees the troops near the start of the novel, on his way to meet his uncle, having confidently bid farewell to his childhood home. Filled with conventional "illusions" (13) about the life that awaits him "among rich and respected gentlefolk of my own name and blood" (10), he looks on with "great pleasure and wonder", hypnotised by the spectacle of order and conformity:

I beheld a regiment marching to the fifes, every foot in time; an old, redfaced general on a grey horse at the one end, and at the other the company of Grenadiers, with their Pope's-hats. The pride of life seemed to mount into my brain at the sight of the redcoats and the hearing of that merry music.

As David Daiches remarks, David is "innocently, yet, in the light of subsequent events, ominously, thrilled" (72). The brutal, suppressive role of the army is not fully revealed 
Bogle Petterson 24

until David sees the soldiers in the Highlands, "coming from Fort William into Appin, against the poor tenantry of the country" $(K 115)$. But the steady, serene march of events that the army suggests to David is soon disrupted: his uncle Ebenezer is determined to bar him from his inheritance, first by attempting to murder him, then by having him abducted.

David's bewildered reaction to his uncle's attempt on his life is characteristic. Although he initially assumes command, locking Ebenezer in his bedroom overnight, he is at a loss as to how to proceed. David perceives that Ebenezer has "lied to [him] at every word" (30), but proves incapable of acting on his own behalf: with no script to follow, he cannot take any steps toward adulthood. With one law-giver exposed as a liar, David can only resort to a higher, supposedly more truthful, official law - whose representative is the lawyer Rankeillor - to bestow the status upon him. This is, in fact, what happens at the end of the novel, and Rankeillor concludes that "'the happiest consequences seem to flow when a gentleman consults his lawyer and takes all the law allows him'" (203). Thus the simple story of "a poor lad that was a rightful heir and a wicked kinsman that tried to keep him from his own" (25) (as David puts it to himself) is apparently resolved.

By the end of Kidnapped, however, the moral authority of the law itself has been eroded. As Alan tells David, the Campbells have cheated the Stewarts out of their land with "'lying words, lying papers, tricks fit for a pedlar, and the show of what's legal over all" (78). This view of the law, which David does not initially take seriously, is brought home to him in Catriona, when the Lord Advocate Prestongrange declares that justice is subordinate to "wpolitical necessity" (36). The law is not an external arbiter, which distributes wealth or land based on some objective standard of merit, but rather a tool wielded by those in power for their own ends: for the tenantry of Appin, to follow Rankeillor's advice and take "“all the law allows [them]"” would be to submit to the legal theft of their lands. Just as political circumstances favour the Campbells rather than the Stewarts, the law favours David over his uncle. Kidnapped inverts the stereotype of the 
undisciplined, lawless Highlander, which was used to justify the military suppression of the country (see Womack 11-12): those with the law on their side are shown to be undeserving of the benefits it affords, since they have not put in any honest effort; Alan contrasts the Campbells' legal machinations with honourable combat: "“[they] got lands of us by treachery - but never with the sword"” (K 78). Similarly, by enlisting Rankeillor, David avoids a personal showdown with his uncle, and this leaves him with a sense albeit not one that he can fully acknowledge - that he does not deserve his wealth and the status it brings with it:

[T]he beggar in the ballad had come home; and when I lay down that night on the kitchen chests, I was a man of means and had a name in the country. Alan and Torrance and Rankeillor slept and snored on their hard beds; but for me, who had lain out under heaven and upon dirt and stones, so many days and nights, and often with an empty belly, and in fear of death, this good change in my case unmanned me more than any of the former evil ones[.] (my emphasis 215)

The image of the "beggar in the ballad" signals David's re-entry into a conventional storybook ending. It is also remarkably apt, since David has not taken his inheritance for himself, but has instead begged for Rankeillor and Alan to do so for him: it is the image of one who has put himself at the mercy of others. An interesting contrast suggests itself between David and the beggars he has met in the Highlands, who "stood on their dignity, asked alms only to buy snuff by their account and would give no change". These David compares favourably to "lowland beggars", who "had a louting, flattering way with them" and who give change (102). For the Highlanders, begging is a necessity forced on them and they will not allow themselves to be defined by it: they refuse to be seen, or to see themselves, as beggars; in the lowlands, begging is treated as a full-time profession, a way of life. 
David becomes "a man of means" and gains respectability ("a name in the country") but is paradoxically "unmanned" by the fact that these things have simply been bestowed upon him. According to Alan Sandison, David's "anxiety" reflects the fact that he is unprepared for adulthood: he "never achieves, or feels that he achieves, maturity and independence". Sandison is certainly correct that David's "complacency and illusory selfsufficiency [. . . are] radically challenged" by his experience in the Highlands, and that rather than achieving genuine "self-sufficiency", as in a traditional Bildungsroman, David in a sense becomes "more passive; self-pitying instead of self-assertive, and more dependent" by the end of the book (190). Yet I would suggest that the problem lies in the nature of adulthood itself, as it is presented in Kidnapped: David does not achieve "independence" because that is not what Lowland society offers. By the end of the novel, David's adventures among lawless, childish primitives have indeed left him unprepared for the dull comforts and conformity of adult civilisation. Rankeillor, the novel's chief representative of maturity, is distinguished by his "complacency" and his "dependence" on the law; Ebenezer is a fragile, terrified shut-in; even David's kidnapper, the seemingly more assertive Captain Hoseason, is only able to carry out his ruthless trade thanks to his split personality - "in fact he was two men" (42) - and is thoroughly conformist while on shore.

The effect of the conventional quest narrative that frames Kidnapped, and pushes David into the adult world, is closely related to the function of the law. Both serve to reduce and label, to remove identity while seeming to bestow it. In fact, the legal system is self-contained and one-sided, blind only in the sense that it refuses to admit problematic evidence. This is most obvious in Catriona, when Prestongrange arranges for David to be abducted - that is, removed from the plot -so that he cannot give evidence in defence of James of the Glens in the Appin murder trial. In Kidnapped, Rankeillor must affect blindness when he meets Alan at the end of the novel, and urges David to omit mention of 
Bogle Petterson 27

any Highland outlaws in the narrative of his adventures. The lawyer also suggests that David tell his "“Odyssey [. . .] in a sound Latinity when your scholarship is riper"” (200) which would de-historicise and de-politicise the events and strictly limit David's readership. Latin, it transpires, is something of a code-language for entry into upper-class adult society, and when they first meet, Rankeillor tests David with a line from Horace. The esteem in which David and Rankeillor hold the dead language contrasts starkly with David's utter ignorance of Gaelic, which is spoken by thousands, and points to the stifling, textual nature of the society David is entering. Indeed, Kidnapped exhibits a profound distrust of writing, as indicated by Alan's reference to the "“lying words, lying papers"” of the law. David's entry into Rankeillor's "dusty chamber full of books and documents" (196) makes him feel uncomfortable, as though he does not fit in. That is precisely the function of writing in Kidnapped and of the letter of the law in particular - to induce conformity and to exclude discordant elements. The reductive, narrow nature of writing is also a feature of Catriona, in which "written documents are associated with corruption and conspiracy" (Reid 163).

This scripted, adult culture is countered in Kidnapped by the spoken culture of the Highlanders; as an oral language, Gaelic is depicted as spontaneous and engaged. During the eighteenth century, as Penny Fielding notes, the "actual oral tradition in the Highlands was actively discouraged, and modern Gaels maligned for their low standards of literacy" (10). Peter Womack suggests that even the handful of eighteenth-century romantic primitivist writers who idealised Gaelic as "the language of nature" (131) nevertheless saw it as part of the past and accepted English as "the language of Improvement" (134). Illiteracy was taken as proof that the childish Highlanders required paternalistic intervention. According to Ashcroft, "education and literacy [became] crucial in the imperial expansion of Europe, establishing ideological supremacy, inculcating the values of the colonizer, and separating the 'adult' colonizing races from the 'childish' colonized" 
Bogle Petterson 28 (39). Stevenson, however, subverts the supposed supremacy of the literate culture over the oral one, and by extension of adult colonizer over childish colonized. In his two-part essay "Talk and Talkers", Stevenson describes a good talk as "a return to the sincerity of savage life from the comfortable fictions of the civilised" (83). This notion dates back to Rousseau, who "opposed the obtrusiveness and aridity of written culture to the purity and immediacy of the spoken word" (Rose 49). For Stevenson, however, the return to "savage life" does not entail privileged access to some fount of pure wisdom: rather, "[t]alk is fluid, tentative, continually 'in further search and progress' [. . .] and speech runs forth out of the contemporary groove into the open fields of nature, cheery and cheering, like schoolboys out of school" ("Talk" 71-2). Indeed, "[c]onclusions [. . .] are not often reached by talk any more than by private thinking" (76). By contrast, "[w]ritten words remain fixed, become idols even to the writer, found wooden dogmatisms, and preserve flies of obvious error in the amber of truth" (71). The virtue of "savage" speech - which is also childish ("schoolboys out of school") - is a negative one, in the sense that it resists the imposition of "fixed", dogmatic, idolatrous meaning, in favour of expansive selfexpression. As Fielding puts it, "Stevenson consistently identifies speech with the natural, but the natural with the plural and the disruptive. Writing is associated with containment and speech with excess" (135). Unlike the textual Rankeillor, Stevenson saw the best kind of storytelling as that which "imitates [. . . speech. [...] The real art that dealt with life directly was that of the first men who told their stories round the savage camp-fire" ("A Humble Remonstrance” 136).

In Kidnapped, David is literally contained by what he has absorbed from written words. When he is washed up on Earraid, following the wreck of the Covenant, he laments that his situation does not conform to a Robinson Crusoe scenario:

In all the books I have read of people cast away, they had either their pockets full of tools, or a chest of things would be thrown upon the beach 

along with them, as if on purpose. My case was very different. I had nothing in my pockets but money and Alan's silver button; and being inland bred, I was as much short of knowledge as of means. (93)

David longs for authorial intervention, but the island is completely barren, leaving him in despair. It is the apparent uniqueness of his predicament ("My case was different") that frustrates him. In order to escape, David is forced to drop his story-book expectations and engage with the unfamiliar speech of a Highland fisherman. After a struggle to make sense of the Highlander's broken English - which to David sounds more like Gaelic, a language he does not understand - he learns that Earraid is only an island at high tide. What was "fixed" in his mind by written accounts of shipwreck ("the comfortable fictions of the civilised") becomes fluid and indeterminate thanks to speech: Earraid is both an island and not an island.

As a spoken language, Gaelic emerges in Kidnapped as the language of improvisation which disrupts the scripted nature of civilised society. Following the "Siege of the Round-House" chapter, Alan regales David with a Gaelic song in honour of his (Alan's) swordsmanship. Composed "in the hour of our victory" (70), and in a childish spirit - "[Alan's] eyes were as bright as a five-year-old child's with a new toy" (69) - it is an intriguing contrast to Rankeillor's suggested composition. David translates the song into "the king's English", but is unable to do so in verse. Hence the real song, which Alan composes entirely in his head, escapes the narrative and remains in the realm of speech. It is personal, unapologetically partisan and vain and yet, David tells us, Alan "sang it often afterwards, and the thing became popular" (69). Although David complains about Alan's vanity, and the fact that he is not mentioned in the song, he accepts that "in good prose talk, Alan always did me more than justice" (70). Vanity, for the Highlander, does not preclude generosity; Stevenson depicts the Highlander's selfishness in much the same way as he describes Walt Whitman's: "sympathy pairs with self-assertion" ("Walt Whitman" 

96). In "Talk and Talkers", Stevenson insists that "[t]rue talk should have more body and blood, should be louder, vainer and more declaratory of the man" (81); but at the same time, this very vanity causes talkers to "overflow the limits of their ordinary selves" (73). Rankeillor, sitting in his study surrounded by books, is thoroughly contained and selfeffacing: his talk is that of "quiet persons, with no very high opinions of their own", who "[seek] out every cranny to avoid offence" (K 200) - an adult contrast to Alan's "childish propensity to take offence and pick quarrels" (84). The lawyer's aversion to conflict does not render him ideologically neutral, however, as it requires that he adapt to the opinions of his social milieu; if he does not "take offence and pick quarrels" this is because he turns a blind eye to offensive details. Discussing the persecution of the Covenanters in the seventeenth century, Stevenson wrote: "one gets more truth out of one avowed partisan than out of a dozen of your sham impartialists - wolves in sheep's clothing - simpering honesty as they suppress documents" (Letters, Vol. I 214). Stevenson portrays Rankeillor much more gently than this, but the lawyer's eagerness for David to omit details “obnoxious to the law"” ( $K$ 199) from his account of his adventures clearly foreshadows the much more hypocritical and oppressive legal officials in Catriona. In Kidnapped, the missionary Mr. Henderland, who David meets in Morven, favourably compares the honest, if bloody, Highlanders to hypocritical Lowlanders, telling David: “"There's many a lying sneck-draw sits close in kirk in our own part of the country, and stands well in the world's eye, and maybe is a far worse man"'. Alan is childish, but because of his sincerity he is "“a chield to be respected", from whom "“we might take a lesson"” (112).

The content of Alan's verses suggests a further contrast between his vain, childish attachment to his "toy" and the function of such objects in the mature, civilised world. Alan sings of his intimate connection with and knowledge of his sword:

This is the song of the sword of Alan:

The smith made it, 
The fire set it;

Now it shines in the hand of Alan Breck. (69)

These lines are remarkably like those in Stevenson's poem "My Treasures" in A Child's Garden of Verses, in which the young narrator recounts the unique origin and personal significance of his favourite possessions: some "nuts", "gathered in autumn by nursie and me"; a "whistle", made "Of a branch of a plane, with a knife of my own"; a "stone" that he is certain is "gold" ("Though Father denies it");

But of all my treasures the last is the king,

For there's very few children possess such a thing;

And that is a chisel, both handle and blade,

Which a man who was really a carpenter made. (54)

Like the child, Alan takes pride in the uniqueness of his toy: he is able to tell, and become part of, its story. Furthermore, as the member of a primitive society, Alan feels connected to the mode of sword-production: it is as though the sword had been made for him personally. By contrast, when David enters Edinburgh in Catriona he purchases "a plain sword, to suit with my degree in life. I felt safer with the weapon, though (for one so ignorant of defence) it might be called an added danger" (4). David's feeling of safety derives from the fact that, despite being practically useless or even dangerous, the sword helps him to fit in. He does not care that it is "plain", or that many other young men must have similar swords, for that is precisely the point. Significantly, he buys the sword immediately after buying new clothes. Like the rest of David's costume, it reduces him to what is expected of him, to his "degree in life" - it is part of a role prescribed by adult society. Alan, as "the child, the primitive" (Robson 102), is free from such impositions, and is able to treat his belongings as extensions of himself.

In both novels, the difference between Highlanders and Lowlanders is revealed in 
their different attitudes toward clothes. When David first meets Alan he is struck by the latter's "fine" and "costly" French clothes (57), and assumes that this is a sign of his high rank and wealth ("a man with so fine a coat must like fine people" (62)). As David soon discovers, however, Alan "had no other" coat (72); his "vanity in dress" (100), which David is wont to smile at, derives from the fact that his coat, like his sword, is an extension of himself (he refuses to change his clothes even when he is being pursued on suspicion of murder). Alan's "childish vanity" (62) is again closely related to his generosity: the gift of a silver button to David is meaningful because it is a part of Alan. As David tells us: "when I saw what care [Alan] took to pluck out the threads where the button had been cut away, I put a higher value on his gift" (73). It is as though Alan has given David a piece of his flesh and must cleanse the wound. Indeed the button is recognised as Alan's throughout the Highlands: he "overflow[s] the limits of [his] ordinary sel[f]", physically as well as in speech.

For David, on the other hand, clothes have a limiting effect: they are merely a costume or uniform, signifying the prescribed role and status of the wearer, and indeed reducing him to that role. In the Highlands, David is unsettled by the multiplicity of "makeshift" outfits: "The Highland dress being forbidden by law since the rebellion, and the people condemned to the lowland habit, which they much disliked, it was strange to see the variety of their array" (101). Finding an elderly couple who are polite and hospitable, David is surprised, as they seem to be playing a part which does not suit their clothes: “[. . .] this old gentleman (I call him so because of his manners, for his clothes were dropping off his back) heard me all through with nothing but gravity and pity" (101). As Barry Menikoff notes, David "carries with him the prejudices (albeit not the hostility) of his own country" (Narrating Scotland 42): "the Highlanders' dress - particularly the philabeg, or kilt - was perceived by the Lowlanders as well as the English as the visible sign of an alien and barbaric people" (41). David never really sheds this prejudice. When 
Bogle Petterson 33

he returns to Queensferry near the end of Kidnapped he immediately feels out of place, primarily because of the ragged Highland clothes he has acquired: dressed "in such a pickle of rags and dirt" he cannot bring himself to ask directions to Rankeillor's house, thinking that to do so would invite laughter ( $K$ 195) (the alienating effect of the town contrasts with the hospitality of the Highlands); later he catches Rankeillor "look[ing] a little ruefully from his clean chair to my muddy rags" (196). After the lawyer has heard his story, David is relieved, again partly because of Rankeillor's dress:

I could not contain my satisfaction. I had been so long wandering with lawless people, and making my bed upon the hills and under the bare sky, that to sit once more in a clean, covered house, and to talk amicably with a gentleman in broadcloth, seemed mighty elevations. (my emphasis)

The natural order of things seems to David to have been restored: the Lowland gentleman wears gentlemanly clothes. His serene reflections are undermined, however, by his own outfit: "Even as I thought so, my eye fell on my unseemly tatters, and I was once more plunged in confusion" (201). David's confusion stems from the fact that his clothes tell a story which is at odds with his surroundings - that is, the story of his adventures in the Highlands. Although Rankeillor gives him "some clothes that belonged to his son" (201), David has mixed feelings:

[...] blythe was I to look in the glass and find the beggar-man a thing of the past, and David Balfour come to life again. And yet I was ashamed of the change too, and above all, of the borrowed clothes. (202)

David feels he has recovered his identity by changing his clothes - even though he is ashamed that they are "borrowed". Like his clothes, David's adult identity is not something achieved through experience; rather it is the result of discarding his old clothes, which bear the disturbing imprint of his adventures. 
Bogle Petterson 34

In fact, David struggles, with some success, to remain insulated throughout his Highland adventure. As critics have often noted, he is largely incapable of action ("On the whole, things happen to him, while [Alan] is the one who does things" (Robson 102); he "exhibits lamentably little ability to take control of events" (Sandison 193)). Moreover, even when he does act, his actions are generally not preceded by serious reflection, in part because, as Menikoff puts it, "the experiences of life come quicker than the occasions for reflection" ("Introduction" xxvii). In Lettermore, for instance, he wonders "why I was going to join myself with an outlaw and would-be murderer like Alan, whether I should not be acting more like a man of sense to tramp back to the south country direct", but just as his doubts become "stronger than ever", his train of thought is interrupted by the arrival of the "Red Fox" (116). At other times, as when David warns Alan that the crew of the Covenant is plotting to kill him, he disowns his act: "I have no credit by it. It was by no choice of mine, but as if by compulsion" (62). David remains intellectually aloof, even as he is emotionally stirred into action by Alan's plight. Likewise, although he sympathises with the Highlanders' suffering, he is unable to side with them politically: although he feels "no good will" toward "King George's troops" when he sees them mobilised against the Stewarts (115), he later insists, when he takes part in a Jacobite toast, that he "wished no ill to King George" (160); again, when he and Alan are attempting to convince a girl in Limekilns to help them cross the Forth to Queensferry, he declares that despite being on the run from the law, "King George has no truer friend in all Scotland than myself." (192).

David's effort to resolve - or, rather, to ignore - the contradiction between his morally troubling sympathy for a savage, Highland outlaw and his sense of his own superior and unspoilt lawfulness, proves increasingly difficult, and finally reaches an impasse during his quarrel with Alan. Henry James judged this to be one of the bestwritten chapters in Kidnapped, particularly because "we feel [the quarrel] to be inevitable, 
though it is about nothing, or almost nothing, and [. . .] springs from exasperated nerves and the simple shock of temperaments" (159). As Buckton rightly points out, James ignores the fact that the quarrel arises from "the deep political and cultural divide between the two protagonists" (142), and is sparked by "David's puritan objections to Alan's gambling" (141) during their visit to a Jacobite chief in the previous chapter. David begins the quarrel so as to assert both his maturity ("Alan had behaved like a child and (what is worse) a treacherous child" ( $K$ 168)) and his civilised status ("“I mean you shall henceforth speak civilly of my King and my good friends the Campbells" (173)). To do this, however, he must abstract himself from the adventures he and Alan have shared: “"Both the Campbells and the Whigs have beaten you; you have run before them like a hare [. . .] It behoves you to speak of them as of your betters"" (174), he tells Alan, as though David himself had not been with him in the heather; he even imagines withdrawing from life itself, if it refuses to fit his desired pattern: "I began to glory in the thought of [. . . death [. . .]. Alan would repent then, I thought" (172). In as much as the quarrel stems from David's desire to disown his journey, to impose a set of received clichés about Highlanders, there is a sense in which it really does come from nowhere; even the landscape seems to rebel against his attempt to contain and reduce: "every glen gushed water like a cistern; every stream was in high spate, and had filled and overflowed its channel" (171). David seems to sense that his mature, civilised persona is incongruous; paradoxically and despite scolding Alan's childishness, David senses that he is "behaving badly" (169), finds himself speaking rudely like "a boy of ten" (171) and sulking like "a sick, silly and bad-hearted schoolboy" (172). His supposedly authoritative, detached adult rhetoric ("the comfortable fictions of the civilised") collapses upon itself no sooner than it is uttered:

'Mr Stewart, [. . .] you are older then I am, and should know your manners. Do you think it either very wise or very witty to cast my politics in my 
Bogle Petterson 36 teeth? I thought, where folk differed, it was the part of gentlemen to differ civilly; and if I did not, I may tell you I could find a better taunt than some of yours'. (173)

The insult which follows further down the page, undercuts David's pretentions to maturity: "'the best I can say of [Highlanders] is this, that they would be none the worse for washing"' (173). David's narrative breakdown reveals that the authority of such adult, civilised rhetoric is not innate but contingent on force. Rankeillor can afford to "differ civilly" because, in the end, he has the power of the law behind him. David, at least while he is in the Highlands, does not have this luxury, and can only fall back on direct taunts "the sincerity of savage life". Although David is angry with himself for not sticking to a mature script, for reverting to savagery and childhood, his newfound vanity and directness endears him to Alan: “'Deed and I don't know,' said Alan. 'For just precisely what I thought I liked about ye, was that ye never quarrelled; - and now I like ye better!" ( $K$ 176).

Just the same, despite his lapse - or perhaps precisely because of this disturbing glimpse of freedom - David retains his longing for the stability of the adult Lowlands. His willingness to be domesticated after his time in the wild Highlands is conveyed by a startling image: as he waits opposite Rankeillor's house in Queensferry, he sees “a chasedog sitting yawning on the step like one that was at home" and admits that he envies the "dumb brute" (195). Stevenson feared dogs more than wolves, he wrote in Travels with a Donkey in the Cevennes, because a dog "represents the sedentary and respectable world in its most hostile form", having "something of the clergyman and something of the lawyer" (237). In his essay "The Character of Dogs" he again complains that dogs are too docile and civilised: "like the majority of men, [they] have but foregone their true existence and become the dupes of their ambition" (102). There is something especially ominous about David's identification with a "chase-dog" given what he has been through in the 
Highlands - to escape the English soldiers he and Alan had to, in Alan's phrase, “" play at being hares"' ( $K$ 154). Although David's fate is not spelled out at the end of Kidnapped, there is nevertheless the implied danger that, after all he has been through, he may yet join the "marching army" of events. This threat persists in Catriona, in which David is both attracted and repelled by the Edinburgh elites: he remains anxious that his shifting allegiances "gave me a look of running with the hare and hunting with the hounds that was little to my fancy" (5). As Reid observes, his "[a]dult ambitions undermine his heroism and moral certainty" (165). This political indeterminacy is matched by a kind of arrested adolescence, as David wavers between the comforts of adulthood and the sincere, heroic but unstable world of the savage-as-child.

Both novels exhibit a scepticism about civilisation that is closely linked to a scepticism about maturity. As he enters Edinburgh and becomes "a man of means [... with] a name in the country" ( $K 215)$, David is stripped of agency, as Kidnapped's final sentence indicates: "The hand of Providence brought me in my drifting to the very doors of the British Linen Company's bank" (219). The sense that David is dwarfed, rather than elevated, by his entry into modern society anticipates Stevenson's Pacific works. In these, as we shall see, European colonists are themselves depicted as infantile in their inability to learn from their surroundings, and in their clinging to story-book notions of their own supremacy. 


\section{Chapter 2}

\section{Infantilisation in "The Beach of Falesá" and The Ebb-Tide}

When Stevenson and his family set sail in 1888 to explore the Pacific, there was a wellestablished tradition of typing Pacific islanders as children. Rod Edmond describes a "hardening" of the trope as the nineteenth-century progressed and as the imperial powers acquired more territories and increased the exploitation of their subjects. For early missionaries - often working in isolation from, or prior to the establishment of, colonial outposts - the childish native could, in a sense, grow up by converting to Christianity. Describing the depiction of natives in the missionary William Ellis' Polynesian Researches (1829), Edmond writes: "Like children, Polynesians are strongly marked by original sin but potentially redeemable" (111). Later in the nineteenth century, as part of "a general shift away from the more benevolent paternalism" of the likes of Ellis, the savage-as-child analogy "could be redefined so that the savage became a permanent child, incapable of growing up" (157), in order to justify the permanent rule of the "adult" colonizers. The theory of recapitulation (which I discussed in the "Introduction") lent a degree of scientific credibility to the analogy, as it was re-formulated in more overtly racial, rather than simply religious terms.

But it would be a mistake to view this as a smooth or homogenous development. The old, "more benevolent paternalism" persisted, as missionary work in the Pacific continued alongside, and in a somewhat ambivalent relationship to the new trading outposts, plantations and colonial governments. Stevenson, who read Ellis' famous work as well as every other book he could find on the Pacific, seems at times to reflect the missionaries' attitudes in his own writings. Although he was critical of the missionaries' hand in suppressing native cultures, he appears to have preferred their "benevolent 
Bogle Petterson 39

paternalism" to what he saw as the far more destructive role played by colonial officials. "Illogical as it may sound," argues Ann C. Colley, "Stevenson paradoxically looked to missionary culture as a refuge for what moral goodness or vitality remained after various foreign intrusions. He saw the Mission Stations and Institutions as centers where the islanders could find and develop strengths within themselves to oppose forces that were detrimental to their future" (30).

Of course, for all its supposed benevolence, today's readers will recognise the missionaries' outlook as nonetheless patronising and racist. Yet in Stevenson's writings the patronising tone, while certainly present, is often accompanied by a sense of the importance of preserving indigenous cultures from the harmful effects of colonialism. In his less pessimistic moments, Stevenson was even able to envision a future in which Samoans shaped their own society without the assistance of foreigners. Speaking to Samoan chiefs shortly before his death in 1894, Stevenson urged them:

There is but one way to defend Samoa. Hear it before it is too late. It is to make roads, and gardens, and care for your trees, and sell their produce wisely, and, in one word, to occupy and use your country. If you do not others will. (“Address to Samoan Chiefs, Vailima” 122)

In a speech to Samoans studying to become preachers, Stevenson compares natives to children in order to encourage them to nurture and advance their own culture, independently of their colonizers: the Samoans themselves must become "the fathers and the guides of [their] race" (“Address to Samoan Students, Malua" 71). As Colley observes, the speech "twist[ed] the parlance of imperialism that referred to natives as children spinning the language on itself - and turn[ed] an all too familiar colonial cliché on its head so as to defeat the deadly consequences of colonial rule" (30). Childishness here symbolises growth, rather than subordination. Stevenson's description of Polynesians in In the South Seas as "barbarous children" is quoted by one critic as an example of the racism 
Bogle Petterson 40 he had absorbed (Saposnik 87). But Stevenson uses this phrase while praising a missionary who has treated the "barbarians" with relative respect: "His method with the natives was extremely mild. Among these barbarous children he still played the part of the smiling father; and he was careful to observe, in all indifferent matters, the Marquesan etiquette" (In the South Seas 62-3). Part of what Stevenson admires is the willingness of this "father" to adopt the customs of his "children", rather than simply to demand adherence to his own customs. ${ }^{7}$ Such passages support Julia Reid's argument that Stevenson's earliest Pacific work, the series of articles collected posthumously as In the South Seas, "hovers on the edge of a new anthropological relativism" (148). While it undeniably shows the influence of contemporary paternalistic attitudes, Edmond notes that, as the book progresses, Stevenson shows "a growing independence [. . .] from the tropes and conventions of the dominant late nineteenth-century Western discourse of the Pacific".

Edmond adds, however, that "[s]ome of these [tropes] persist" in Stevenson's writing, among them "the recurring infantilisation of Pacific cultures and peoples" (167). But Stevenson's engagement with this trope is far from conventional. Certainly at times Stevenson does indeed parrot the more common, patronising and racist comparisons of natives to children - sometimes reducing them to mere passive onlookers, rather than active or complex agents. What I aim to show in the following discussion, however, is that in general the "infantilisation" in his Pacific works departs, quite consciously, both from the "benevolent" paternalist and the more overtly racist uses of the trope. As in Kidnapped, the primitive-as-child (Uma in "The Beach of Falesá" or the Samoan soldiers in $A$ Footnote to History) is often depicted as courageous and vigorous, rightfully rebelling against an "adult" colonizer who lacks any claim to authority. Moreover, Stevenson's Pacific works show that he was attune to the way the trope was deployed to justify

7 Stevenson's partiality for missionaries in the Pacific who "went native" recalls his similarly sympathetic portrayal of the Edinburgh missionary Mr Henderland in Kidnapped. Henderland admires the Highlanders and criticises the oppressive laws prohibiting their traditional dress, telling David, "'Ye'll perhaps think I've been too long in the Highlands?'” (112) 
Bogle Petterson 41 imperialism, and he satirises its imperialist uses: most significantly, at various points in these works the trope is in a sense reversed to reveal the infantile barbarism of imperialism itself. The aged decrepitude of colonial civilisation becomes, in the figures of Case, Captain Randall and Wiltshire in "Falesá", the four protagonists of The Ebb-Tide and the German officials in A Footnote to History, a "second childishness", to use Shakespeare's phrase (As You Like It, II, vii). In the terms of postcolonial theory, the childish barbarism that these colonists reject as "Other" turns out to be a version of what lies at the heart of imperialist psychology. Each of these characters, in different ways and to different degrees, represents a subversive mockery of the ideal romantic colonial adventurer, while the stories and non-fiction in which they appear subvert what Bill Ashcroft describes as the "romance of youthful adventure" in the colonies, motivated by "the desire for moral, physical and racial regeneration". This is a genre among whose popularisers, as I have already noted, Ashcroft unjustly includes Stevenson, alongside H. Rider Haggard and Rudyard Kipling (41). The childishness of Stevenson's whites has none of the youthful vitality of Stevenson's childish natives, nor does it promise any kind of "regeneration" - it is, rather, a final stage of decay, characterised by bigotry, greed and self-absorption.

Examining Stevenson's subversion and reversal of the child/savage trope in his anti-imperialist works helps show just how radical, innovative and influential they were. A strikingly similar reversal can be found in the works of Joseph Conrad, to which "Falesá" and The Ebb-Tide are frequently compared. Amar Acheraïou argues that Conrad's Heart of Darkness

links Kurtz and implicitly empire to infantilism. In defining Kurtz - a white protagonist - through the child trope, which usually characterises the natives, Conrad challenges to an extent the colonial representation of whiteness alongside the authority and sense of supremacy it entails. (81)

As the personification of imperialism's worst excesses, Kurtz's authoritarianism comes to 
Bogle Petterson 42 resemble an "infantile state of myness" (81), as he "reduce[s] the world to a selfreproducing mould [...] turn[ing] the Africans and the ivory into objects of fantasy and self-gratification. Just as he feverishly toys with the ivory he collects for the Company Kurtz toys with the natives' lives as a child would in his games" (79). As well as being infantilised, Acheraïou notes that Kurtz is linked very strongly to savagery - he fetishises his ivory, and is depicted as a cannibal $(79,80)$. In fact, Kurtz's reversion to childhood is fundamentally bound up with his reversion to barbarism. It is highly plausible, I would suggest, that the savage-infantilism of Attwater, Case and Wiltshire directly influenced Conrad's depiction of Kurtz.

At the same time, there are important differences between Kurtz and Stevenson's white villains in the Pacific. There is some critical controversy over the extent to which Kurtz's descent into barbarism is intended to reflect the "reversion to barbarism" which Marxists saw as the outcome of imperialism (Friedrich Engels, quoted in Luxemburg 111), as opposed to what Patrick Brantlinger calls "the nightmare of "going native" (Rule of Darkness 39). In a compelling analysis, Brantlinger argues that the "ingenious inversion" in Heart of Darkness, through which Kurtz's European "ideals" are turned into mere "idols", certainly critiques imperialism, but does so in racist terms: "Conrad portrays the moral bankruptcy of imperialism by showing European motives and actions to be no better than African fetishism and savagery. [. . .] In short, evil is African in Conrad's story; if it is also European, that's because some number of white men in the heart of darkness behave like Africans” (“Heart of Darkness: Anti-Imperialism, Racism or Impressionism?” 393). How does Stevenson's portrayal of his imperialist characters, and their reversion to infantile savagery, compare? I would argue that Stevenson's dubious or villainous characters have not degenerated as the result of "going native": their savagery is imported from Europe. ${ }^{8}$ Stevenson himself was quite clear on this matter with regard to "Falesá",

8 As Lawrence Phillips writes: “"The Beach of Falesá' shows us not the threat of degeneration, but a degeneration that is already internalised by the European characters[. . . .] Unlike Heart of Darkness, 
Bogle Petterson 43 writing to his friend Sidney Colvin: "And will you please to observe that almost all that is ugly is in the whites?" (Maixner 411). In his last letter to Colvin before his death in 1894, Stevenson, angry at his friend's indifference toward the fate of the Samoan people, wrote: "It is the proof of intelligence, the proof of not being a barbarian, to be able to enter into something outside oneself, something that does not touch one's next door neighbour in the city omnibus" (Vailima Letters 272). This echoes his statement in In the South Seas that "the traveller must rouse and share" a "sense of kinship" with the natives (13), and his admiration for the missionaries who adopted native customs. Indeed, in "Falesá" the only morally outstanding white character is the missionary Tarleton - and missionaries, we are told by the resentful Wiltshire, are "partly kanakaised, and suck up with natives instead of with other white men like themselves" (148). Part of what readers are meant to admire about Wiltshire himself is that, in spite of his faults, he too ends up "going native", choosing to stay in the Pacific and start a family with Uma rather than return to England to open a pub. Conversely, in Stevenson's Pacific works, it is precisely in the assertion of their paternalistic aloofness from native civilisation that the representatives of European civilisation reveal their barbarism and childishness. The desire to set up a rigid, hierarchical binarism between adult-coloniser and child-colonised is revealed to be an infantile and barbaric craving. The remainder of this chapter will examine the infantilisation of whites and natives in "Falesá" and The Ebb-Tide, while the next chapter will address A Footnote to History, Stevenson's most radical work of non-fiction.

where it is the exposure to the so-called 'primitive psyche' and the primal bush that reawakens Kurtz's 'savage' subconscious, Stevenson's vision suggests that it is the westerners themselves who contaminate local cultures, peoples and politics, encouraging greed, competition, drunkenness, violence and deceit" (75). Barry Menikoff also argues that the "savagery" in "Falesá" is "linked to white behaviour rather than Polynesian practices" ("A Study in Victorian Publishing" 58). 


\section{"The Beach of Falesá": Going Native as Growing Up}

It is in relation to "The Beach of Falesá" that Stevenson's tendency to type Polynesians as children has been most widely discussed. The central problem for critics has been how to reconcile what they see as Stevenson's more or less straightforwardly racist portrayal of the natives of Falesá with the story's apparent subversion of the narrator Wiltshire's racism. Another way of putting this has been to ask to what extent Wiltshire's infantilisation of the natives of Falesá is shared by Stevenson as author, and to what extent is it satirised. Some argue that Stevenson's portrayal of the natives does not significantly diverge from Wiltshire's: Robert Kiely asserts that "Wiltshire's insensitive and condescending observations are thoroughly borne out by the behaviour of the characters. Uma and the other natives do act and speak like children" (71); similarly, Peter Gilmour argues that "there is nothing in the South Sea Island stories to counter the view that, for Stevenson, the natives were simple, passive, incapable of effective resistance”. According to Gilmour, Stevenson's "notion of natives as childlike and impressionable" allows him to "dodge" questions of colonial oppression raised by the story: "Everything in the narrative must be subordinated to the struggle between the decent white man and the bad white man” (192). In a somewhat more complex reading, Katherine Linehan agrees with Kiely and Gilmour that "the Polynesians in the story, including Uma, act and speak like children while being relegated to the role of passive onlookers to a struggle which vitally affects them", but argues that "the perpetuation of partly benevolently-inclined stereotypes about non-whites does not preclude a well-founded indignation over the callous exploitation of Polynesians by whites" (364). Linehan suggests that "even while Stevenson myopically perpetuates racial and sexual stereotyping in his creation of the Polynesian characters, he far-sightedly and obviously with some degree of authorial control reproduces his own recapitulationist stereotypes in his creation of Wiltshire. [. . . It is as though through the 
imaginative freedom conveyed by this narrative mask, Stevenson were able to see himself whole and create a translated, slightly caricatured working-class version of himself to experiment with his own ideas" (366-7). Rod Edmond similarly argues that in "Falesá" the child-as-savage analogy, one of "Stevenson's own cherished categories", is "held at arms length": "By putting this sentiment in Wiltshire's mouth the satire is doubled, reflecting back on author as well as narrator, and constituting the deepest level of the story's exploration of the complexities of white racism" (174).

"Falesá" is undoubtedly one of Stevenson's most radical works. But both Linehan and Edmond overstate the extent to which putting the savage-as-child trope "in Wiltshire's mouth" represents an act of authorial self-criticism or transcendence. It is true that Stevenson portrays Uma and the other natives of Falesá as children, but their childishness does not at all conform to Wiltshire's racist notions. Linehan notes in passing that Stevenson's depiction of Polynesians as children "takes on overtones of indulgent paternalism in keeping with his long-standing romantic interest in childhood" (363). Certainly many of Stevenson's writings on Polynesians do show signs of "indulgent paternalism", in keeping with conventional stereotypes. But Stevenson's own "romantic interest in childhood" in fact diverges from these stereotypes, constituting a valorisation of childhood which, when it appears in his Pacific works, is deployed in opposition to the crude racism of characters like Case and Wiltshire. The natives of Falesá are in fact less passive than these critics will allow: although Wiltshire certainly conceives of them as such, the narrative itself undermines this conception. What is revealed in the process is Wiltshire's childish reliance on a set of colonial clichés, which he must grow out of (to a degree) by the end of the story, in order to marry Uma.

In order to understand the dynamics of Stevenson's use of childishness in "Falesá", whereby the childishness of the natives is valorised while the whites are infantilised so as to undermine their authority, it is instructive to look briefly at his two key essays on 
children. The early "Notes on the Movements of Young Children", as we have already seen, describes children as possessing "a sincerity, a directness, an impulsive truth" reminiscent of primitive humans. In Emersonian fashion, Stevenson praises the nonconformity of children, their immunity from adult-civilised conventions: "the child tries to dance for its own pleasure, and not for any by-end of ostentation or conformity" (200). The essay is critical of adults who, "looking on critically" and laughing, are unable to appreciate the sincere efforts of children to express themselves (198). The longer "Child's Play" is less whimsical and more deferential to adults. The latter, after all, possess "the capacity to enjoy Shakespeare" (106), "they know more than when they were children, they understand better, their desires and sympathies answer more nimbly to the provocation of the senses, and their minds are brimming with interest as they go about the world" (108). Children, on the other hand, inhabit a "world of dim sensation" (112): they "see and touch and hear through a sort of golden mist" (107); their "experience is incomplete" (110) and they are unconcerned with making sense of reality, preferring "the shadow to the substance" (112). Yet this essay too is ultimately a defence of childhood and an attack on disciplinarian adults. Children, Stevenson suggests, "dwell in a mythological epoch, and are not the contemporaries of their parents". In a radically relativistic way, Stevenson counters his own picture of children as irrational beings by asking adults to consider "the dread irrationality of the whole affair [i.e. the standards and conventions of the adult world] as it seems to children" (114). From the child's point of view, adults "care so little for rational enjoyment, and are even the enemies of rational enjoyment in others" (109); they are "unthinkable deities", "who profess the tenderest solicitude for children, and yet every now and again reach down out of their altitude and terribly vindicate the prerogatives of age" (114). For Stevenson, it is precisely in their efforts to induce conformity in children, and their failure to consider things from the child's point of view, that adults reveal their own irrationality. 
By typing Polynesians as children, I would suggest, Stevenson ultimately aims to reveal the irrationality of adult-colonisers in the Pacific. The latter, like the adults Stevenson criticises in "Child's Play", consistently refuse to look beyond their conventions, to "enter into something outside [themselves]". The relativistic reversal at the heart of "Child's Play", whereby the irrational fantasies of children are balanced against the irrational disciplinarian conventions of adults, is repeated in "Falesá", in which the white traders are depicted as no less superstitious, and far more barbarous, than the natives. Timothy Hayes suggests that while "Child's Play" “draws a contrast between children's and adults' uses of stories", it also "reveals just how comparable (and interdependent) both may be" (161). That is, the fantasies of children, which form "a veritable cocoon in which confusion is easily ignored" (163), are comparable to what Stevenson refers to as the adult's "little incongruous theories about life" ("Child's Play" 108). "Child's Play" points to the dangers that arise when adults continue to think from within the "cocoon" of their social conventions, and unthinkingly attempt to impose them on others - that is, when they refuse to "grow up". With Hayes, I would argue that the behaviour of European characters in "Falesá" and The Ebb-Tide shows this same infantilism, as these characters irrationally isolate themselves from native society and cling to their "civilised" conventions - or to their megalomaniacal view of themselves.

In "Falesá", Wiltshire's childishness is most apparent when he allows himself to be duped by Case, his only commercial rival on the island. As soon as Wiltshire sets foot on Falesá, Case befriends him and arranges his sham marriage to Uma. Unbeknownst to Wiltshire, Uma is tabooed, and as the taboo rubs off on Wiltshire, none of the islanders will trade with him - giving Case an effective monopoly. Case's powers of persuasion are extraordinary, almost supernatural. He is referred to as "Tiapolo" by the natives, meaning "“big-chief devill" (161) (as Uma explains to Wiltshire), and he has convinced the islanders that he derives mysterious powers by worshipping the actual devil in a temple 
Bogle Petterson 48

deep in the bush. For Gilmour and others, the fact that Case is able to dominate the islanders so completely indicates their fundamentally passive role in Stevenson's imagination - their "inability to manage intelligent opposition" (Gilmour 192). Yet it is significant that in order to gain control of the island Case has bought the assistance of the native pastor Namu and has colluded with one of the native chiefs, Maea. As Tarleton tells Wiltshire: "with a certain following among the chiefs, and the pastor in his pocket, [Case] was as good as master of the village" ("Falesá" 154). Wiltshire perceives that Maea "could never have been really frightened [of Case's supposedly demonic powers], and must have just made believe from dodginess and because he thought Case had a strong pull in the village and could help him on" (172). Moreover, until he uncovers Case's trickery, Wiltshire himself is thoroughly manipulated by his rival, and so are all the other white characters in the story.

Case's power of manipulation is bound up with his ability to assume a role - to play-act. As Wiltshire says near the start of the story, Case is capable of adapting himself to any company:

No man knew his country, beyond he was of English speech; and it was clear he came of a good family and was splendidly educated. [. . .] He could speak when he chose fit for a drawing room; and when he chose he could blaspheme worse than a Yankee boatswain and talk smut to sicken a kanaka. The way he thought would pay best at the moment, that was Case's way; and it always seemed to come natural and like he was born to it. (117)

This description is strikingly similar to that of one of Stevenson's most famous villains, Treasure Island's Long John Silver. Jim Hawkins learns from Israel Hands that Silver “"had good schooling in his young days, and can speak like a book when so minded"”. But, as Jim observes, Silver has "a way of talking to each [crew member]" on the Hispaniola (54), and indeed is not above ridiculing bookish language in order to appeal to anti- 
intellectual prejudices (59). Early in the book, Jim is plagued with nightmares in which Silver appears to him "in a thousand forms, and with a thousand diabolical expressions" (5) - a description which anticipates Jim's final disgust with the pirate captain's “constant changes" (181). As with Case, however, these very "changes" are the source of Silver's charm, and are the means by which he controls his pirate crew and manipulates the novel's gentleman-heroes. In particular, Silver's manipulation of Squire Trelawney - which enables the pirate captain to secure jobs for his co-pirates aboard the Hispaniola - can be compared with Case's manipulation of Wiltshire. When he meets Trelawney, Silver takes advantage of the squire's patriotism to ingratiate himself, and Trelawney confidently reports to Dr. Livesey and Jim that Silver's missing leg was “'lost in his country's service, under the immortal Hawke"" (38). As the story progresses, Trelawney is shown to be largely incapable of thinking beyond the rhetoric of patriotism. Following an altercation with Captain Smollett he tells Livesey: "'I declare, I think his conduct unmanly, unsailorly, and downright un-English"” (50). Upon learning of the pirates' mutiny, the scandalised Trelawney exclaims: “"And to think they're all Englishmen!”" (66). Like Silver, Case is adept at seducing and manipulating his rival by establishing a "bogus camaraderie" (Hayes 168) based not on patriotism (Case's nationality remains a mystery) but on the rhetoric of racism. ${ }^{9}$ When Wiltshire tells Case that he believes he has been tabooed, Case replies: "'I don't know where the impudence of these kanakas 'll go next, they seem to have lost all idea of respect for whites"”; "'Understand me, Wiltshire, I don't count this your quarrel,' he went on with a great deal of resolution; 'I count it all of our quarrel, I count it the White Man's Quarrel, and I'll stand to it through thick and thin, and there's my hand on it'” (135, 136). Like Trelawney, Wiltshire is easily taken in: "Altogether I was pretty well pleased with his attitude" (136). Both are duped because of their childish insularity, their reliance on a very limited set of prejudices: as Hayes observes, "It is as though Case has read

9 Intriguingly, in both Treasure Island and "Falesá" the talent of manipulating others by appealing to their prejudices is linked to politics: Case "had the brains to run a parliament" (138), while Silver has ambitions of using his share of the treasure to become a member of "Parlyment" (TI 61). 
Bogle Petterson 50

another Stevenson story entitled 'The Isle of Voices' in which one of the main characters, a Hawaiian named Keola, twice asserts that 'white men are like children and only believe their own stories" (168). Both characters, in echoing "the comfortable fictions of the civilised" ("Talk and Talkers" 83), are in some ways like the adults in "Child's Play" who see the world "through theories and associations as through coloured windows" (107-8). Yet the "theories" which sustain Stevenson's colonial characters are so narrow and reductive, and so linguistically impoverished, that they also come to resemble an infantile, cocoon-like state. Like children, Stevenson's Europeans "can make abstraction of whatever does not fit into [their] fable" (110).

What is perhaps most interesting is that Wiltshire's infantilism is revealed precisely as he belittles, and indeed infantilises, the natives of Falesá. When Wiltshire accompanies Case on a visit to the island's chiefs, he is supremely confident that they will remove his taboo:

I know how to deal with kanakas; give them plain sense and fair dealing, and I'll do them that much justice, they knuckle every time. They haven't any real government or any real law, that's what you've got to knock into their heads; and even if they had, it would be a good joke if it was to apply to a white man. It would be a strange thing if we came all this way and couldn't do what we pleased. (137)

Yet Wiltshire does not know the first thing about the natives. He cannot even understand their language, and has to rely on Case to translate, "or [make] believe to, rather" (137). His helplessness derives from his self-imposed isolation from native society. Before coming to Falesá, he says at the opening of the story, "I had been for years on a low island near the line, living for the most part solitary among natives" (emphasis added 115). Initially, indeed, he does not see natives as fully human: when he first sees Uma, she appears to him to possess "a sly, strange, blindish look between a cat's and a baby's" (119). 
Bogle Petterson 51

Shortly afterwards Wiltshire describes Uma's mother, Faavao, as "like a child" and "like a great cat" as she delivers "a quantity of poetry in my praise because I was to marry Uma". Indeed, he refers to Faavao at first as “the thing”: “'Who in the devil's this?' cried I, for the thing startled me" (122). What is revealed in both examples is Wiltshire's almost comic inability to connect on a human level to either of these characters, largely because he cannot understand their language. His attempt to contain the natives within his conventionally racist and infantilising rhetoric is never quite successful, as is revealed by the incongruous description of Uma as both "sly" and babyish. Barry Menikoff notes that Stevenson's editors altered this phrase, substituting "shy" for "sly", as well as deleting Wiltshire's description of Uma as a "cutty sark" (a Scots phrase which means "both a short skirt and a saucy wench"), apparently in order "to tone down the portrait of Uma as a truly seductive woman". The editorial changes removed the "ambiguity" of the original description, in which Uma appears to Wiltshire as "innocent and experienced, childlike yet mature" (“A Study in Victorian Publishing” 83). Indeed, Wiltshire's view of Uma is highly unstable: after their sham wedding, he likens her to "a child or a kind dog", in an attempt to reduce and domesticate her - yet at the same time Wiltshire himself behaves like a dog. He begins to fall in love with Uma, and as they walk toward his house the best I could do was just to follow her whenever she went on, to listen to her bare feet, and to watch in the dusk for the shining of her body. And there was another thought came in my head. She played kitten with me now when we were alone; but in the house [during the wedding ceremony] she had carried it in the way a countess might, so proud and humble. [ . . it] came over me she was a kind of a countess really, dressed to hear great singers at a concert, and no even mate for a poor trader like myself. ("Falesá" 125)

Such emotions tend to intrude into the narrative unannounced, disrupting Wiltshire's view of himself as a superior white man. As Menikoff notes, Wiltshire often 
"declares his control over the events described and experienced. Yet it is an irony that the more Wiltshire declares his control the less he actually possesses" (“A Study" 39). This is because the language of domination employed by Wiltshire is nothing more than a set of received clichés, which point to Wiltshire's childish insulation from the realities - and superstitions - of Falesá. Stevenson's tale shows how the latter overwhelm Wiltshire on an emotional level, while on an intellectual level he retains his racist views. At one point, while alone in the bush, Wiltshire is strangely affected by what he calls "the queerness of the place" (165). He has just heard Uma's disturbing "yarns" about devils disguised as women or beasts, which the islanders believe to haunt the forest. He is quick to assure readers, however: 'Don't think it was Uma's yarns that put me out; I don't value native talk a fourpenny piece: it's a thing that's natural in the bush, and that's the end of it" (166). Much is contained in this sentence. The trader's metaphor of "value" is highly suggestive: it points to the truth about imperialist activity in the Pacific, which was of course driven by the need for profits and was completely indifferent as to the opinions of natives. For an individual white trader who absorbed this ethos, an entire world of experience was sealed off, rejected as worthless. This failure of the colonial imagination and its disastrous consequences are dramatised by Stevenson in his cautionary tale "The Bottle Imp", which contains a very similar statement to Wiltshire's. The white boatswain, who appears at the end of that tale, having purchased the wish-granting bottle, dismisses the Hawaiian protagonist Keawe's warnings that the owner of the bottle is damned to eternal suffering in hell. He tells Keawe: “I don’t value any of your talk”" (189). Throughout "Falesá”, "native talk" is contrasted with European "value". Unlike the boatswain of "The Bottle Imp", however, it is clear that despite himself, Wiltshire is profoundly affected by "Uma's yarns". When, venturing deeper into the island, he hears the sound of Case's "Tyrolean harps", he says: "I tell you the truth; I had made up my mind to see an aitu [devil]" (167). Even after he has exposed Case's "devil-work" as fraudulent, "Uma's stories significantly 
Bogle Petterson 53

retain an undiluted power" (Reid 155). As he prepares to blow up Case's temple in the dark, Wiltshire admits: “It wasn't Case I was afraid of, which would have been common sense; I never thought of Case; what took me, as sharp as the cholic, was the old wives' tales, the devil-women and the man-pigs"; when Uma appears in the dark, he initially mistakes her for a "devil-woman" ("Falesá” 178).

Native talk exerts a powerful influence on Wiltshire, albeit not one he is able to acknowledge. As we have seen, in "Talk and Talkers" Stevenson valorised speech as opposed to what he saw as the rigidity of written words, and in "Falesá", as Reid points out, writing is "represented critically [. . .] as an instrument by which European colonists manipulate and exploit native cultures" (155). The fake marriage certificate, drawn up by Case, declares that Uma "is illegally married to $\underline{M r}$ John Wiltshire for one night, and $\mathrm{Mr}$ John Wiltshire is at liberty to send her to hell next morning" ("Falesá" 124). At the end of the story, when Tarleton and the village chiefs "seize Case's papers", all they find is "a bit of a diary, kept for a good many years, and all about the price of copra and chickens being stolen and that; and the books of the business, and the will I told you of in the beginning, by both of which the whole thing (stock lock and barrel) appeared to belong to the Samoa woman [Case's wife]" (185). Case does not use writing to communicate or engage with others, but to designate ownership of both people and copra. The written documents in "Falesá" can be compared to the numerous treaties and legal documents used to rob Pacific islanders of their land (as well as the "'lying words"” used to dispossess the Highlanders in Kidnapped). They represent the stories that the white man tells himself, and by which he gives himself license to do as he pleases. Paradoxically, in order to grow up, to appreciate the stories of others, Wiltshire must abandon the written word and engage with the oral culture of the Falesáns. Thus, suffering from a crisis of conscience, Wiltshire tears up his sham marriage certificate and asks the missionary Tarleton to perform a new ceremony “"in native"” (151). Reid argues against Linehan's claim that Stevenson's "use of Beach-la- 
Mar infantilizes the Polynesian characters", pointing out that "this pidgin is represented approvingly: less rigid than written language, it allows Wiltshire and Uma to negotiate a linguistic middle ground between their distinct cultures" (156). While this is correct, I would argue that the approving representation of orality in "Falesá" does not preclude a positive portrayal of the native society as childish. Despite his initial, patronising description of Uma as a baby, Wiltshire later describes a happy domestic scene in which "we cooked each a dish, helping and hindering each other, and making a play of it like children" (“Falesá" 143). This recalls Stevenson's description in "Child's Play" of how children invent dinner-time games in order to make their meals more palatable (106). In "Talk and Talkers" Stevenson described talk as childish ("speech runs forth out of the contemporary groove [. . .] like schoolboys out of school" (72)) and vitally engaged, "continually "in further search and progress"” (71); Stevenson argues that "it is in talk alone that we can learn our period and ourselves" (72). To the extent that Wiltshire "goes native" he must shed the infantile insularity of colonial culture and immerse himself in native speech, taking up once more what Stevenson described as "the first duty of man" (72) to learn his period and himself. ${ }^{10}$

Wiltshire describes how, following his second, legitimate, wedding ceremony, he and Uma are visited by the French Catholic missionary Galuchet, typically referred to as "Galoshes"11 by the islanders, who continues his education:

The same night of our wedding Galoshes called round, made himself mighty civil, and got into a habit of dropping in about dark and smoking his pipe with the family. He could talk to Uma of course, and started to teach

10 Stevenson's positive portrayal of childish, primitive speech conforms, to some extent, to what Ashcroft identifies as the "reshap[ing]" of the child/savage trope "into a vision of post-colonial possibility" (3). As I argued in the introduction to this thesis, this "vision" has its roots in eighteenth-century primitivism and romanticism.

11 That Wiltshire refers to Galoshes by the corrupted, phonetic version of his name is ironic given that he complains that the natives mispronounce his own name as "Welsher" (149) or "Vilivili" (172). (He tells Tarleton: "Wiltshire is the way it's spellt, if the people on the beach could only get their tongues about it" (149)). The more textual Case, by contrast, always gives the priest's name "the French quirk, which was another reason we had for thinking him above the common" (132). 
me native and French at the same time. He was a kind old buffer, though the dirtiest you would wish to see, and he muddled me up with foreign languages worse than the tower of Babel.

That was one employment we had, and it made me feel less lonesome; but there was no profit in the thing; for though the priest came and sat and yarned, none of his folks could be enticed into my store[.] (158) Like Tarleton, Galoshes is very much "kanakaized" (or "gone native"), and this is portrayed positively in the story. ${ }^{12}$ In In the South Seas, Stevenson stresses the need to overcome the "impediment of tongues" (10) in order to view Polynesians as human. He describes his frustration when a group of Marquesans boarded his ship and proved "beyond the reach of articulate communication, like furred animals" (that is, just as Uma and her mother first appear to Wiltshire); Stevenson "had journeyed forth out of that comfortable zone of kindred languages, where the curse of Babel is so easy to be remedied; and my new fellow-creatures sat before me like dumb images" (9). In "Falesá", however, Galoshes' native speech, no less than Uma's, is declared unprofitable, even as Wiltshire recognises that it makes him "feel less lonesome". What clearly emerges from his contradictory statements is that it is precisely the colonial fixation on profits - that is, on copra - which leads to childish insularity and loneliness. Profit, in fact, is linked to childishness early in the story. When Uma realises that Case has duped Wiltshire into marrying her by concealing the fact that she has been tabooed, she says:

'Now I go 'way, taboo he go 'way too. Then you get too much copra. You like more better, I think. Tofá alii,' she says in the native - 'Farewell chief!'

12 Galoshes recalls another Catholic missionary, also criticised for his dirtiness and for choosing to live among natives, who Stevenson vigorously defended: namely, Father Damien, who worked in the leper colony on the Hawaiian island of Molokai. In his polemical letter defending Damien, Stevenson writes, approvingly, that Damien "had fallen (as other priests so easily do) into something of the ways and habits of thought of a Kanaka; but he had the wit to recognise the fact, and the good sense to laugh at [...] it" ("Father Damien: An Open Letter to the Reverend Dr. Hyde of Honolulu" 34-5). "Going native" is an occasion not for stern moralizing, but for laughter; it is a sign of Damien's engagement with native society, as opposed to the detachment of his well-heeled critic in Honolulu, the Protestant missionary Dr. Hyde. 
'Hold on,' I cried. 'Don't be in such a blamed hurry.'

She looked at me sidelong with a smile. 'You see, you get copra,' says she, the same as you might offer candies to a child. (my emphasis 141-2)

Wiltshire seems to take Uma's statement as a sign of her simplicity, but the story shows it to be perceptive: the white traders on the island do indeed have an infantile obsession with copra. ${ }^{13}$ Wiltshire is only able to set aside his need for the product in spite of himself, thanks to his love for Uma. He is unable to account for his own actions: "'Uma,' I said, 'I would rather have you than all the copra in the South Seas,' which was a very big expression, and the strangest thing was that I meant it" (142). Stevenson wrote to Colvin that Wiltshire "has surely, under his beast-ignorant ways, right noble qualities" (Vailima Letters 129), but as Linehan points out, Wiltshire "is converted [to egalitarianism] far more strongly at the emotional than the intellectual level" (371). Narrating from a position of commercial supremacy (having killed Case and moved to a different island), Wiltshire appears to have learnt remarkably little from his experience on Falesá; indeed, at the end of the story, the need for profits triumphs, as Wiltshire admits he "was half-glad when the firm moved me on to another station, where I was under no kind of pledge [i.e. his pledge to Tarleton that he will "'deal fairly with the natives"'], and could look my balances in the face" ("Falesá" 186). Moreover, although he comes to accept Uma as "an A one wife", Wiltshire's attitude to his children remains disturbingly ambivalent: "what bothers me is the girls. They're only half castes of course; I know that as well as you do, and there's nobody thinks less of half castes than I do; but they're mine, and about all I've got; I can't reconcile my mind to their taking up with kanakas, and I'd like to know where I'm to find them whites?" (186). This disturbing ending shows that Wiltshire still childishly clings to "the comfortable fictions of the civilised", even while his parental feelings pull him in the

13 For Stevenson, copra was essential to the story. When its editors deleted an anecdote that Case relates to Wiltshire about his commercial triumph over a former rival, Stevenson complained to Colvin: "your omission of the little copra story seems to me very illogical; that is the preparatory note to Case, and the whole tale: the reader must be shown how far men go, and Case has gone, to get copra" (qtd. in Menikoff, "A Study" 92). 
opposite direction. His growth, symbolised by the fact that he has become a father, is thereby undermined, even while his offspring represent the promise of growth and possibility for native culture itself.

All the same, Wiltshire is in a healthier position than the other "father" in the story, Captain Randall. Randall is ironically called "the father of the Beach" (119) and referred to as "papa" by Case (121); in fact, as Patrick Brantlinger points out, he is "a degenerate, boozy representative of that usually noble species the British sea captain" (Rule of Darkness 40). Wiltshire is disgusted at the sight of Randall:

His body was covered with gray hair and crawled over by flies; one was in the corner of his eye - he never heeded; and the mosquitoes hummed about the man like bees. Any clean-minded man would have had the creature out at once and buried him; and to see him, and think he was seventy, and remember he had once commanded a ship, and come ashore in his smart togs, and talked big in bars and consulates, and sat in club verandas, turned me sick and sober. ("Falesá" 121)

As Stevenson pointed out when defending this portrayal, Randall is "essential as a pawn in the game, Wiltshire's disgust for him being one of the small, efficient motives in the story" (Vailima Letters 129). It is "partly for [Uma's] sake, and partly for horror of the recollection of old Randall" that Wiltshire decides to pour out his supply of gin ("Falesá" 126). Alcoholism features prominently in Stevenson's Pacific stories as a sign of his white characters' childish self-absorption and isolation from native society. Randall is never seen outside his house, while Wiltshire's drinking habits are connected to his "four years at the line, which I always counted years of prison; getting tabooed, and going down to the Speak House to see and get it taken off; buying gin, and going on a break, and then repenting; sitting in my house at night with the lamp for company; or walking on the beach and wondering what kind of a fool to call myself for being where I was" (117). "The Bottle 
Bogle Petterson 58 Imp" suggests a connection between alcoholism and imperialist psychology: the white boatswain's first wish, having acquired the bottle imp, is for a bottle of rum; the imp itself, which allows its owners to acquire massive riches but only at the expense of others, offers a kind of drunkenness: the numbing of the senses, the infantile narrowness of vision, which is the ethos of imperialist accumulation. In The Ebb-Tide this link is even more obvious, as Captain Davis and Huish, in their drunken callousness and cruelty towards the native crew of the schooner Farallone, come to symbolise incompetent and tyrannical colonial administrators. ${ }^{14}$ Alcoholism is one means by which Stevenson's white characters regress to "the child's world of dim sensation, [where] play is all in all" ("Child's Play" 112), where communication breaks down (Randall's speech is less intelligible than the pidgin "Beach de Mar" which Wiltshire and Uma speak to each other) and where the needs of others can be ignored.

From what has been said, it may appear that Case, as the one white character in "Falesá" most actively involved in native society, escapes being trapped by the rhetoric of imperialism. As Vanessa Smith puts it, Case exhibits remarkable skill as "a two-faced mimic of settler and indigenous practices" (290), whose "success lies in his ability to negotiate between cultures, and to play upon mutual assumptions" (287). Case's shapeshifting is at times highly comical, as when he tells Wiltshire that there is no way to persuade the natives to set foot in his store:

'The kanakas won't go near you, that's all. And who's to make 'em? We traders have a lot of gall, I must say; we make these poor kanakas take back their laws, and take up their taboos, and that, whenever it happens to suit us. But you don't mean to say you expect a law obliging people to deal in your store whether they want to or not? You don't mean to tell me you've the gall for that?' (“Falesá" 140)

14 As Colley notes, the Farallone "is a microcosm of imperialist society" (39). 
This mock respect for native customs comes shortly after some of Case's most emphatically racist statements. Case's engagement with native society is thoroughly pragmatic: he appears to be above both native and white superstitions, and is even capable of manufacturing his own. Yet his manipulation, in the end, is also a form of infantile isolation from native society. According to Smith, "His name signifies the subject both of detective fiction and, avant la lettre, of the psychoanalytic session" (285), emphasising his elusiveness. It also suggests his essential hollowness - he is a mere box of tricks - and his isolation from native society: he is encased, so to speak, in his performances. Case has learned to manipulate "native talk" (as well as western prejudices) in order to secure profits, but he sees no more inherent "value" in it than Wiltshire does. When he tells Wiltshire that they would be able to better "manage" the kanakas if they possessed a German "man of war" ("Falesá" 135), one suspects that this is what Case really would $\operatorname{prefer}^{15}$, rather than having to "negotiate between cultures". In short, Case regards the inhabitants of Falesá not as people with requirements of their own but as toys with which he may do as he pleases. Though in many respects he "plays the role of the originator of stories that children then preserve through play" (Hayes 168), rather than a child in thrall to the stories of others, he nevertheless believes that he may do whatever is necessary to make a profit. The native belief that Case worships a devil at his temple in the bush is, in a sense, correct: as Wiltshire discovers, Case surrounds the temple with forged "island curiosities", "fresh as toys out of a shop", so that it "served the man a double purpose: first of all to season his curiosities, and then to frighten those that came to visit him" ("Falesá" 168-69). These "idols" (168) or "toys" are created not to appease any native deities, but for the sake of profit, that European devil which wreaked so much destruction in the Pacific. In the end, with the exception of his Samoan wife, all that remains of Case are his will, a diary detailing the changing price of copra, and "the books of the business" (185), which

15 As Roslyn Jolly notes, "Case probably has in mind the Samoan war of December 1888, when German men-of-war fired several times on native villages" (South Sea Tales 263). 
Bogle Petterson 60

symbolise the story governing his existence, for the sake of which other tales are spun.

\section{The Infantile Insularity of Imperialism in The Ebb-Tide}

The barbaric nature of imperialism is even more starkly revealed in Stevenson's last completed work, which opens by stating: "Throughout the island world of the Pacific, scattered men of many European races and from almost every grade of society carry activity and disseminate disease” (ET 122). As Roslyn Jolly observes, “just about everyone [in the novel] is savage, except the savages (and, perhaps, Herrick)" ("The Ebb-Tide and The Coral Island" 83). I suggest that the white characters in the novel (including Herrick) are also childishly attached to the myths of their civilisation and insulated from the realities of life in the Pacific. The persistent mythologising of Herrick and Attwater, in particular, recalls G. V. Plekhanov's observation that "[t]he more the falseness of [the master class's] ideology is revealed by life, the more elevated and virtuous does the language of that class become" (81). Stevenson's narrative repeatedly reduces the "elevated" rhetoric of European myth to the level of a childish fairy-tale. At the same time, the native characters in the background of The Ebb-Tide are depicted as dignified, somewhat idealised, mainly passive children (by the second part of the book, the crew of the Farallone seem practically forgotten). They remain the most sympathetic characters in the book, victims of the indifference or exploitation of the white characters. As in "Falesá", the childishness of the whites is revealed most of all in their indifference to and estrangement from the natives.

This estrangement is most extreme in Attwater, the missionary and colonial tyrant who dominates the second half of the novel. In stark contrast to the missionaries in 
"Falesá" and those depicted admiringly in In the South Seas, ${ }^{16}$ Attwater has remained completely aloof from the native population of his atoll, which he rules with an iron fist. Like Wiltshire, who prior to coming to Falesá lived "for the most part solitary among natives" ("Falesá" 115), Attwater describes himself as a "'lonely man"”, whose only company is God (ET 214). Attwater, however, is much more deliberate than Wiltshire about ensuring his isolation from the natives. In "one of the most important metaphors of The Ebb-Tide" (Jolly, South Sea Tales 286), he points to the diving suits used by his slavelabourers to harvest pearls and tells Herrick:

'Well, I saw these machines come up dripping and go down again, and come up dripping and go down again, and all the while the fellow inside as dry as toast! [. . .] and I thought we all wanted a dress to go down into the world in, and come upscatheless. [. . .]' (ET 202)

This " parable",, as Attwater calls it, is one of a number of stories within the novel, through which Attwater exerts his "power and control" over events (Hayes 177). In his metaphorical diving suit, which he calls “"God's grace”" (ET 203), Attwater has descended into the Pacific while remaining completely insulated from its realities. ${ }^{17}$ In "The Education of an Engineer", Stevenson described his own diving experience in the "subarctic town of Wick" (21) as a thrilling adventure, but one which left him with decidedly ambivalent feelings. ${ }^{18}$ At first, Stevenson connects diving with romantic notions of boyhood discovery: "Youth is a blessed season after all", he writes after describing his

16 Robert I. Hillier has suggested that Attwater is in fact the hero of The Ebb-Tide, arguing that he resembles the missionaries Stevenson admired (133). As Colley points out, however, Attwater is not just a missionary: "he is missionary, trader, beachcomber, and official rolled into one violent, disruptive and unpredictable entity" (39). Stevenson was disturbed by the combination of missionary work with capitalist ventures. He attributed the "failure" of Protestant missionaries in Hawaii largely to the fact that, "In the course of their evangelical calling, they - or too many of them - grew rich" ("Father Damien" 29).

17 Jeremy Treglown notes that "The diving suit symbolized for Stevenson many different ways of staying 'dry as toast' apart from religious faith (what it stands for here). It also meant any kind of protective fiction of self; indeed, fiction tout court" (122). Hayes' thesis is that The Ebb-Tide is "a story about the power of stories" (178) which Attwater, like a child, tells himself in order to justify and perpetuate his rule. It is also, I would argue, a story about the severely psychologically restricting - rather than simply empowering - effect of these stories.

18 Jolly notes that this early episode "provided" Stevenson with the diving-suit metaphor in The Ebb-Tide (SST 286-7). 
first sight of "a mailed dragon with a window-glass snout"; he goes on: "the more rugged excitants of Wick east winds had made another boy of me. To go down in the diving-dress, that was my absorbing fancy; and with the countenance of a certain handsome scamp of a diver, Bob Bain by name, I was gratified the whim". Yet after donning the diving-suit the young Stevenson's feelings change dramatically: "I was cut off in a moment from all my fellow-men; standing there in their midst, but quite divorced from intercourse: a creature deaf and dumb, pathetically looking forth upon them from a climate of my own" (23). One begins to see why Stevenson chose the diving-suit as a metaphor for the experience of a colonist in the South Seas - this last sentence recalls the frustration Stevenson felt during his initial encounter with Marquesans, "beyond the reach of articulate communication" (ISS 9). Even more interestingly, however, Stevenson describes his experience inside the diving suit as a decidedly unromantic regression to childhood: "It is bitter to return to infancy, to be supported, and directed, and perpetually set upon your feet, by the hand of someone else" ("Education of an Engineer" 26). The diving episode, as Stevenson narrates it, clearly foreshadows Attwater's infantile state: cut off from his "fellow-men", Attwater looks upon them through the window of his personal brand of religion; he is "quite divorced from intercourse" with the natives; and he has regressed to a state in which he feels that he is "supported, and directed, and perpetually set upon [his] feet, by the hand of someone else", namely, God. ${ }^{19}$ Attwater tells Herrick that he was brought to the Pacific originally by, among other things, "Youth, curiosity, romance, the love of the sea"" (ET 203). At some point, though, Attwater donned his metaphorical diving-suit, whereupon this youthful curiosity was supplanted by a thoroughly abstracted, insulated and infantile world-view. It is likely that this regression occurred when Attwater found "his" island " "by accident"” and turned it into "“a business, and a colony, and a mission of my own"” (204): like the white characters in "Falesá", Attwater is infantilised by his need for profits.

19 As Herrick puts it, Attwater is a "ffatalist"” who " "believes that his bullets go true; believes that all falls out as God chooses, do as you like to prevent it; and all that"” (222). 
Attwater exhibits the most callous, childish features of Wiltshire, taken to an extreme. Wiltshire describes himself as "one of those most opposed to any nonsense about native women" ("Falesá" 125), yet he is completely seduced by Uma. Attwater is much more steadfast; when Herrick points out a "pretty" woman on the atoll, one of the few natives who has survived the recent smallpox epidemic, Attwater replies that she is "Too pretty" and explains that he has had her married off so that he might avoid temptation:

'A man never knows when he may be inclined to be a fool about women; so when we were left alone, I had the pair of them to the chapel and performed the ceremony. She made a lot of fuss. I do not take at all the romantic view of marriage[. . . .] I am a plain man and very literal. Whom God hath joined together, are the words, I fancy. So one married them, and respects the marriage'[.] (ET 210)

As for himself, Attwater says that he " may look to make an excellent marriage when I get home" (210), thanks to the fortune he has accumulated in pearls. During his ten years on the atoll, Attwater has managed to remain thoroughly uncontaminated by contact with the local population: as Hayes observes, his "identity never seems to have been threatened by his new life in the South Seas" (177). Attwater is like the child in "Child's Play" who "can make abstraction of whatever does not fit into his fable; and [. . .] puts his eyes into his pocket, just as we [adults] hold our noses in an unsavoury lane" (110; see also Hayes 173). As Hayes argues, Attwater is a highly contradictory figure but " he possesses a mature sense of what needs to be done to preserve his position that is accompanied by a childlike assurance that whatever he believes is true and an equally childlike ability to make abstraction of anyone or anything that stands in his way" (Hayes 174). Attwater shuts his eyes to the suffering of the natives he exploits, treating them "as something closer to dolls or toy soldiers than human beings" (175); indeed they are no more human to him than the pearls themselves, which Attwater describes as "Gewgaws"” (ET 210), a word defined by 
Bogle Petterson 64

the Oxford English Dictionary as a "gaudy trifle, plaything, or ornament" (my emphasis).

His attitude exemplifies Aimé Césaire's view of colonisation as "thingification" (Discourse 21); although Attwater criticises the more conventional South Seas missionaries for their superficial obsession with natives' clothes (ET 203), he goes on to tell Herrick: "I dislike men, and hate women; if I like the islanders at all, it is because you see them here plucked from their lendings, their dead birds and cocked hats, their petticoats and coloured hose"” (205). ${ }^{20}$

Attwater echoes Wiltshire's disdain for "native talk", but much more emphatically, telling his guests: “The native who talks, like the woman who hesitates, is lost. You set him talking and lying; and he talks, and lies, and watches your face to see if he has pleased you"” (218). Unlike Wiltshire, Attwater has resisted any engagement with the natives on a human level, as is suggested by his mythologised view of himself: "“I gave these beggars what they wanted: a judge in Israel, the bearer of the sword and scourge"' (204). Attwater views his surroundings entirely through the filter of mythology; he has named his island Zacynthos, after an isle in Virgil's Aeneid, and appears to conceive of himself as the actor in a grand, divine stage-play. At the dining table, he tells his white guests that despite the emptiness of the smallpox-ravaged island, "“we sit in this veranda on a lighted stage with all heaven for spectators! And you call that solitude?"' Yet when he does not receive an answer, he admits: "'These are the diversions of a lonely man, [. . . ] and possibly not in good taste. One tells oneself these little fairy tales for company. If there should happen to be anything in folk-lore, Mr Hay?" (214). Religion is thus a comforting "fairy tale" which, childlike, the despot tells himself in order to make his life more enjoyable. Yet Attwater describes his religion as "“a savage thing, like the universe it illuminates; savage, cold, and bare, but infinitely strong"” (204) - like armour, or like Attwater's diving suits, which, indeed, his native servants wear as armour during the confrontation between

20 Stevenson criticised those missionaries who were chiefly concerned with such altering of native clothes: "for the cool, healthy and modest lava-lava or kilt, Tartuffe has managed in many [. . .] island[s] to substitute stifling and inconvenient trousers" (ISS 32). 
Attwater and Davis and Huish (244). Folk-lore is the shell which insulates Attwater from native society, and this detachment makes him as monstrous as the suits themselves, which he refers to as "marine monsters" (202) and which, near the end of the novel, appear to Davis as “demons" unleashed from hell (244).

Attwater is perhaps the most mono-maniacal character in any of Stevenson's works, but the other white characters in The Ebb-Tide - the beachcombers Davis, Herrick and Huish - are each, to a greater or lesser degree, cut off from their surroundings, imprisoned within their own metaphorical diving suits. Their insularity takes the form, in each case, of childish attachment to the mythology of Western civilisation. "Superstition rules all men", we are told by The Ebb-Tide's third-person narrator; "semi-ignorant and gross natures, like that of Davis, it rules utterly" (242). Wiltshire, describing his fear of native devils in the woods of Falesá, perceptively remarks: "We laugh at the natives and their superstitions; but see how many traders take them up, splendidly educated white men, that have been book-keepers (some of them) and clerks in the old country! It's my belief a superstition grows up in a place like the different kinds of weeds; and as I stood there, and listened to that wailing, I twittered in my shoes" ("Falesá" 166). ${ }^{21}$ His susceptibility to local superstitions endears Wiltshire to the reader, as it allows him to transcend his racism, at least momentarily. The superstitions or fairy tales in The Ebb-Tide, however, are all imported from Europe and not one of the characters in the novel has "gone native".

Davis and Huish's superstitions consist mainly of conventional, racist views of the Pacific. When, early in the novel, the destitute trio each write a letter "home", it becomes evident that not one of them is capable of telling the truth about their lives in Tahiti Davis, in fact, refers to the letter-writing as "lying"” (ET 139). Huish's letter to a Northampton barmaid is an example of standard colonial fantasies about the domination of supposedly inferior races: "'I wrote to her, and told her 'ow I had got rich, and married a 
queen in the Hislands, and lived in a blooming palace. Such a sight of crammers! I must read you one bit about my opening the nigger parliament in a cocked 'at. It's really prime'" (142). Later, when they meet Attwater, Huish and Davis are awe-struck by his apparently absolute control of his native slave-labourers; Attwater seems to exemplify the mythic colonial ideal, the white man who achieves godlike power simply by virtue of his whiteness. Davis declares, "in a glow of admiration", that Attwater " "must be a holy terror!" to be able to control his workforce single-handedly. Indeed, as Jolly observes, the second part of The Ebb-Tide is far from realistic, as Attwater's island possesses a "dreamlike atmosphere" (85) in which such imperial romance motifs are presented in a subversive, expressionist manner (in particular, Jolly argues that the novel is an unconscious "rewriting of [R. M. Ballantyne's] The Coral Island as an act of iconoclasm" (87-8)). Davis eventually succumbs to the myth that Attwater has woven around himself and, as he and Huish prepare to murder Attwater, there suddenly comes over Davis,

from deep down in the roots of his being, or at least from far back among his memories of childhood and innocence, a wave of superstition. This run of ill luck was something beyond natural; the chances of the game were in themselves more various; it seemed as if the devil must serve the pieces. The devil? He heard again the clear note of Attwater's bell ringing abroad into the night, and dying away. How if God . . . ? (my emphasis 233)

There is no direct evidence within the narrative to suggest that Attwater has achieved dominance over the natives of his island by any means other than sheer, brutal force; it is Davis, a white man, whose superstitions lead him to attribute divine powers to Attwater. When he and Huish approach the island on their "David and Goliath" mission to murder Attwater, Davis sees two faceless, metallic creatures - two of the surviving natives, dressed in diving-suits - and "his mythology appeared to have come alive, and Tophet to be vomiting demons" (244). 
The fact that Huish attempts to justify murdering Attwater by comparing their rivalry to that of "Dyvid and Goliar"” is highly significant. While aboard the Farallone, Herrick holds "long nocturnal conversations" (167) with the ship's cook, an old man who reveals that his name is "Taveeta, all-e-same Taveeta King of Islael”" (168). Taveeta tells Herrick "his simple and hard story of exile, suffering and injustice among cruel whites" (167) - that is, a genuine tale of David versus the Goliath of empire. Huish and Davis refer to Taveeta belittlingly as "Uncle Ned", after failing to understand his real name, which Davis dismisses as "'highway gibberish" (156), and they prove just as oblivious and indifferent to the plight of Pacific islanders in general. For the latter, the biblical allusion has a real and tragic resonance, and the noble Taveeta is fully deserving of his name, but for the whites the myth is reduced to an analogy in a vicious and childish rivalry. When Davis initially objects to Huish's underhanded, ignoble plan to murder Attwater with a bottle of vitriol, Huish argues in the language of a boy preparing for a schoolyard battle:

“"Now, see 'ere, ducky,' said Huish, 'this is my bean feast, I believe? I'm goin' up to that man single-'anded, I am. 'E's about seven foot high, and I'm five foot one. 'E's a rifle in 'is 'and, 'e's on the look out, 'e wasn't born yesterday. This is Dyvid and Goliar, I tell you!"”(237)

The white characters of The Ebb-Tide repeatedly show themselves to be unworthy of their own mythology, which they have thoroughly perverted and debased to the level of the infantile.

Herrick, though much more educated than his two companions, is no less imprisoned by childish fairy tales. He carries "a tattered Virgil in his pocket" (124) which brings back memories of his "irrevocable youth" in England (125). As a thoroughly textual creature, Herrick presents a striking contrast to Wiltshire: whereas the former is fluent in Latin, the latter cannot even read Roman numerals ("Falesá" 175) and says "Tyrolean harp" instead of Aeolian harp (167); Herrick is deeply literary - when he first sees 
Attwater's island, he "torture[s] himself to find analogies" (ET 188) - while Wiltshire's narrative is decidedly spoken, in plain language. These differences are significant because, for Stevenson, "[t]he culture of the Pacific region had developed outside" "the frontiers of Roman civilisation, which he identified with modernity and the west" (Jolly, "Robert Louis Stevenson and Samoan History: Crossing the Roman Wall” 126-7). In his Pacific travel book, Stevenson wrote that he had

escaped out of the shadows of the Roman empire, under whose toppling monuments we are all cradled, whose laws and letters are on every hand of us, constraining and preventing. I was now to see what men might be whose fathers had never studied Virgil, had never been conquered by Caesar, and never been ruled by the wisdom of Gaius or Papinian. (ISS 9)

This passage identifies western civilisation with decay and ruin ("toppling monuments") as well as unnatural constraints on human activity. The Pacific, by implication, is a youthful land of growth and renewal. In The Ebb-Tide this schema is slightly altered: it is Herrick, the student of Virgil, who clings to his childhood. Whenever he consults The Aeneid, his "oracle", it conjures up

visions of England [. . .]: the busy schoolroom, the green playing fields, holidays at home, and the perennial roar of London, and the fireside, and the white head of his father. For it is the destiny of those grave, restrained and classic writers, with whom we make enforced and often painful acquaintanceship at school, to pass into the blood and become native in the memory; so that a phrase from Virgil speaks not so much of Mantua or Augustus, but of English places and the student's own irrevocable youth.

The classics thus act as a "constraining and preventing" force, a paternal authority, which prevents Herrick from growing up. As someone who has not absorbed any Roman 
mythology, the relatively uneducated Wiltshire is better placed to take Polynesian mythology seriously and thereby, despite his racism, to enter into a relatively equal relationship with Uma. For Herrick, however, all is filtered through his western mythology, his "diving-dress of self-conceit" (229). Indeed, by contrast with all Stevenson's other Pacific writings, native folk-lore does not feature at all in The Ebb-Tide.

As in Kidnapped, Latin serves to block out and cover up experience, while acting as a code-language for the upper-class characters in The Ebb-Tide. But whereas for David Balfour the language allows for entry into an "adult", literate society, as opposed to the "childish" world of the Gaelic-speaking Highlanders, for Herrick Latin is explicitly associated with a regression to childhood. From start to finish, almost, Herrick remains a schoolboy attempting to prove his worth. Despite his half-hearted agnosticism, Herrick conceives of himself, like Attwater, as a character performing to and soliciting approval from unseen deities. This becomes clear when, like a child writing on a classroom blackboard, he scrawls Latin graffiti and "the famous phrase from the Fifth Symphony" on the wall of the abandoned Papeete prison where he, Huish and Davis have been sleeping: “'So,' thought he, 'they will know that I loved music and had classical tastes. They? He, I suppose: the unknown, kindred spirit that shall come some day and read my memor querela. Ha, he shall have Latin too!" (144). Herrick conceives this "'kindred spirit"” very much in his own image, just as Attwater creates a God in his own. Of course, Herrick has none of Attwater's fanaticism: he recognises his own "self-conceit". Yet the significance of this scene in the ruined prison could not be more clear: having escaped to the Pacific from a career in finance "that he detested and despised" (125), Herrick remains imprisoned by the culture that he absorbed in childhood; he paces "[t]o and fro [. . . like a caged brute" even as "his mind whirl[s] through the universe of thought and memory" (143). He thus falls prey to the romantic seductions of Attwater's island, in his way, no less than Huish and Davis are taken in by the tyrant's self-mythologising. When Attwater first boards the 
Farallone, he speaks to Herrick "as an equal", while the others are "pointedly ignored", and Herrick is "pleased [. . .] in spite of himself" (193). As Attwater "fell into the false measure of society [. . .] Herrick unconsciously followed the example" (194). Later, when Herrick goes ashore, he is enchanted: he admires the figure-head on the beach "with singular feelings of curiosity and romance" and "he could have found it in his heart to regret that she was not a goddess, nor yet he a pagan, that he might have bowed down before her in that hour of difficulty" (200). This feeling of romance is heightened when Attwater reveals that he has named the island Zacynthos, after an island in The Aeneid: Herrick appears to have re-entered the Roman empire, that is, the schoolroom of his youth. Like children, the two men bond over their shared story.

Beneath the veil of romance, of course, lies the reality of Attwater's brutal exploitation of the island's native inhabitants. This is a reality which Herrick is never able to fully acknowledge, but it is not long before his youthful feelings of "curiosity and romance" collapse and give way to a sense of infantile powerlessness. When Attwater relates his cold-blooded murder of one of the islanders, Herrick furiously denounces him as a "'murderer and hypocrite". But this denunciation only leads to a dead end, as he convulses "like a frantic child" and dissolves into "indescribable and meaningless sounds" (219). Despite his genuine moral outrage, Herrick simply does not have the psychological capacity to side against the representative of the Roman empire, which has such a powerful hold over his imagination. After Attwater has booted the trio back on board the Farallone, foiling their plans to kill him, Davis tells Herrick: “"you and me have to turn to and think"”; to which Herrick replies petulantly, "I will not think", and shortly afterwards attempts to put an end to thought altogether by escaping through the "open door of suicide" (227).

Herrick's suicide is, however, completely unsuccessful. In his attempt to drown himself, he is rescued by "the diving-dress of self-conceit" (229): the mythology of 
civilised, western society intervenes. As he sinks slowly beneath the surface of the lagoon, Herrick focuses on

A very bright planet [that] shone before him and drew a trenchant wake along the water. He took that for his line and followed it. That was the last earthly thing that he should look upon; that radiant speck, which he had soon magnified into a City of Laputa, along whose terraces there walked men and women of awful and benignant features, who viewed him with a distant commiseration. These imaginary spectators consoled him; he told himself their talk, one to another; it was of himself and his sad destiny. (227-8)

Ultimately, Herrick cannot bring himself to "drop the curtain", to "escape" the stage of life (228). Herrick's struggle under water recalls Stevenson's "bitter [. . . ] return to infancy" inside his diving-suit, "supported, and directed, and perpetually set upon [his] feet, by the hand of someone else". Herrick similarly loses control of his body:

To any man there may come at times a consciousness that there blows, through all the articulations of his body, the wind of a spirit not wholly his; that his mind rebels; that another girds him and carries him whither he would not. It came now to Herrick, with the authority of a revelation. (228)

Herrick's near-death experience thoroughly empties him of the myths that have hitherto sustained and constrained him:

The poor diving-dress of self-conceit was sadly tattered! With the fairy tale of suicide, of a refuge always open to him, he had hitherto beguiled and supported himself in the trials of life; and behold! That was also only a fairy tale, that also was folk-lore. He had no tears; he told himself no stories. His disgust with himself was so complete, that even the process of apologetic mythology had ceased. (229) 
This rejection of mythology does not, however, amount to an acceptance of the realities of life in the Pacific. Rather, Herrick surrenders to Attwater, whom he calls " "cold, cruel, hateful"” but nonetheless "“an honest man, an honest gentleman"” (230). Soon afterwards, Attwater forces Davis to convert to Christianity at gunpoint, reducing the sea captain until he babbles, pleading for mercy, "like a child among the nightmares of fever" (249). Thus both beachcombers submit to Attwater as to a new father. Yet Attwater himself remains little more than a child, inclined to treat them as mere playthings - indeed, he literally toys with Davis' life, treating him like "a puppet" in a "cruel game" (248). Such is the bleak conclusion of one of Stevenson's most pessimistic tales, reflecting his wellfounded fears that European rule in the Pacific could only result in a descent into infantile barbarism. 


\section{Chapter 3}

\section{A Footnote to History: Native Schoolboys and Foreign Bullies in Samoa}

Stevenson's depictions of Attwater and Wiltshire as childish, insulated from the realities of life in the Pacific and indifferent to the lives of its native inhabitants, were drawn from his own observations of European colonizers. His A Footnote to History: Eight Years of Trouble in Samoa provides a detailed account of the machinations and blunders of colonial administrators and diplomats, between 1883 and 1892, as they attempted to maintain control over the nominally independent Samoan government. The book is polemical: Stevenson sided with Mataafa Iosefo, the chief who led a rebellion against the German puppet government of king Tamasese Titimaea. At the same time, it is in many respects a pessimistic work. As John Kucich notes, “Stevenson's advocacy for Samoan independence [. . .] began paradoxically in the conviction that it was already a lost cause" (81) - as Stevenson puts it, "no longer possible" (FH 10). His scathing, clear-sighted denunciations of colonial rule thus sit uncomfortably alongside repeated appeals to the European powers to act in the best interests of Samoa - that is, against their own imperial interests - by allowing Mataafa to govern. Politically, this was a naïve, almost hopeless approach, as Stevenson himself sometimes sensed. In his first letter to the Times on the Samoan "trouble", he wrote: "I despair, in so short a space, to interest readers in their wrongs; with the mass of people at home they will pass for some sort of cannibal islanders; with whom faith were superfluous, upon whom kindness might be partly thrown away" ("Letters to the Times" 245). Yet, as Roslyn Jolly argues, Stevenson was motivated to write his Samoan history by "a degree of partisanship [combined] with a strong sense of public service" (Robert Louis Stevenson in the Pacific 67). ${ }^{22}$ A Footnote to History was conceived as a 
document which would "be useful to the islands" (Vailima Letters 82), particularly, I would argue, by challenging European prejudices about Polynesians. ${ }^{23}$ Thus despite its limitations, Footnote retains a powerful subversive quality in its depiction of the psychology of white officials in Samoa, and in their comparison to "the native actors" (FH $1)$.

In The Devil's Handwriting: Precoloniality and the German Colonial State in Qingdao, Samoa and Southwest Africa, the historian George Steinmetz argues that because Stevenson "addressed Samoans as children and presented himself as a benevolent but pedantic father" he provided a "program" of paternalistic rule which was "developed to a fine art" by Samoa's first German Governor, Wilhelm Solf, who administered the islands after they became an official German colony in 1900 (307). Yet Stevenson's depiction of Samoans as children diverges significantly from imperialistic paternalism. Whereas Solf infantilized the "natives" in order to legitimize colonial rule ("the natives are ignorant," he wrote, "they have to be instructed; they are lazy and have to learn to work [. . .]: they are all big children in need of education and loving guidance" (quoted in Najita 77)), Stevenson, as Susan Y. Najita argues, "employs the metaphor of the child to describe how capitalism created stark differences between Samoans and pālangi" and in order to reveal that the "powerlessness of Samoans [. . . was] a result of gross inequalities under the plantation system" (77). It is worth recalling that in "Child's Play" Stevenson insisted that,

official keeping; and, thanks to the generosity with which you have admitted me to your columns, I stand alone before the public" ("Letters to the Times" 271). Stevenson felt a sense of duty to bring the facts "before the public" which, in the end, trumped his "despair" to interest them in the Samoans' fate.

23 It has been noted that the work is by no means free from British anti-German prejudice. Vanessa Smith suggests that Stevenson's description of the German colonists as humourless and touchy "adds little to a received stereotype" (205); Kucich observes that the "caricature [of] Germans as self-destructive bullies [. . .] square[s] with British racial stereotypes of Germans, Britain's chief late-century imperial rivals" (73). Yet while this may be true, and the Germans are certainly the chief targets of Footnote, Stevenson notes that, in observing their colonial adventures,

No English reader can fail to be reminded of John Company; and if the Germans appear to have been not so successful, we can only wonder that our own blunders and brutalities were less severely punished. Even on the field of Samoa, though German faults and aggressions make up the burthen of my story, they have been nowise alone. Three nations were engaged in this infinitesimal array, and not one appears with credit. (19)

This passage represents a conscious effort to transcend British nationalist prejudices. By comparing the German firm in Samoa to the British East India Company, Stevenson positions Footnote as an attack on imperialism in general. 
from the point of view of the child, adults are "the enemies of rational enjoyment" (109), whose only claims to authority are "the prerogatives of age" (114), namely, superior physical strength. Moreover, I would argue, Stevenson undermines colonial claims to authority by presenting the colonisers themselves not simply as irrational adults, but as bullying children, thereby inverting the metaphor of the savage-as-child.

Like "The Beach of Falesá" and The Ebb-Tide, Footnote is informed by two distinct and opposed notions of childishness. Stevenson portrays his Samoan characters as childish primitives, valorising their childish rebelliousness, their "schoolboy" warfare, and their oral culture and illiteracy. At the same time, the "civilised", "adult" colonists exhibit an insularity and aloofness from native society, a refusal to understand or engage with it, a faith in the power of their written proclamations to transcend the actual state of affairs, and a stubborn belief in the innate superiority of their race - all of which resembles an infantile fantasy. Footnote subverts the notion of imperial adventure as a means to rejuvenate and reinvigorate decaying European society. Heroism, physical adventure and growth are almost entirely the province of the Samoans. The latter are engaged in an effort to come to terms with the world beyond Polynesia, to understand the Europeans. Stevenson relates how, "after Mataafa became involved in hostilities against the Germans, and had another code to observe besides his own, he was always asking his white advisers if 'things were done correctly"". The author urges his readers to "try to be as wise as Mataafa, and to conceive that etiquette and morals differ in one country and another" (5). Throughout Footnote, it is the Europeans in Samoa who refuse to learn from their new environment, or to grow up.

As in the texts I have already discussed, the difference between the "primitive" and "civilised" characters in Footnote emerges prominently in a series of contrasts between literate Europeans and Samoan oral culture. The latter is associated with rumour, the absence of clear authority, indecision, idleness, duplicity and expansive debate - all 
qualities which are in turn associated with childishness. "Important matters", Stevenson writes, "are debated in a fono, or native parliament, with its [. . .] endless speeches and polite genealogical allusions. Debated, I say - not decided" (2). The "king of Samoa" he likens to "the president of a college debating society" whose actual authority among Samoans is "imaginary" (4). Those inclined to read this comment as a belittling of Samoan politics should bear in mind that Stevenson was a member of a college debating society in Edinburgh. In the Edinburgh University Magazine he praised debating societies as the means for a student to "keep his mind fluent and sensitive, keen to mark flaws and willing to surrender untenable positions" and to "keep himself teachable"; further, "[i]t is as a means of melting down this museum of premature petrifactions into living and impressionable soul that we insist on their utility" ("Debating Societies" 151). These qualities - sensitivity, fluency and impressionability - are what characterise the Samoans in Stevenson's history. By contrast, Stevenson referred to the Germans' puppet government as "a still-born child" capable only of "some spasmodic movements" ("Letters to the Times" 260). In Footnote, the German consul, Dr. Knappe, is described as "unteachable by fate"; following the hurricane which sank Germany's warships "he continued, on the scene of his defeat and in the midst of his weakness, to bluster and menace like a conqueror" (FH 111).

Certainly, at times Stevenson was exasperated by the predominance of rumour and gossip, and the absence of final authority in Samoan culture - in Footnote's "Preface" he complains that "Truth, in the midst of conflicting rumours and in the dearth of printed material, was often hard to ascertain" (xvii) - but it is equally clear that this state of affairs appealed to his imagination. "Should Apia ever choose a coat of arms," he wrote,

I have a motto ready: 'Enter Rumour painted full of tongues'. [. . .] Everyone tells everything he knows; that is our country sickness. Nearly everyone has been betrayed at times, and a trifle more; the way our sickness 
takes the predisposed. And the news flies, and the tongues wag, and fists are shaken. Pot boil and cauldron bubble! (13)

Rumour, though not authoritative, has the power to expose and "betray", particularly since the German officials in Footnote typically refrain from attempting to dispel rumours about their misgovernment. For instance, Stevenson mentions the "rumour going uncontradicted" that the chief justice, appointed to Samoa by the three powers (the United States, Great Britain and Germany), occupied a house built by a German official "rent free": "I do not say it is true, I say it goes uncontradicted; and there is one peculiarity of our officials in a nutshell - their remarkable indifference to their own character" (146). In one of his letters to the Times, Stevenson goes even further. Writing of his discovery that the puppet government purchased Samoa's only newspaper in order to suppress it, he remarks: "I have once again to admire the accuracy of rumour in Apia" ("Letters to the Times" 264). The Germans are criticised for remaining "indifferent" to rumour and, by extension, to native opinion in general. In the same letter Stevenson points out that "[i]t is not the whites who menace the duration of their Government, and it is only the whites who read the newspaper" (266). In a society where "[e]veryone tells everything he knows" and "news flies" through the air, Stevenson depicts the Germans as tight-lipped, entirely divorced from the realm of speech, and "distinguished by their literalmindedness - by what emerges as a wilful faith in the power of the written word to resist interrogation" (Smith 205). Stevenson writes:

Other whites take part in our brabbles, while temper holds out, with a certain schoolboy entertainment. In the Germans alone no trace of humour is to be observed, and their solemnity is accompanied by a touchiness often beyond belief. Patriotism flies in arms about a hen; and if you comment on the colour of a Dutch umbrella, you have cast a stone against the German emperor. $(F H ~ 17)$ 
Bogle Petterson 78

Explaining the secrecy surrounding the mistreatment of indentured labourers at the German copra plantation, Stevenson writes that the plantation overseers "keep their business to themselves, rather affect to 'move in a mysterious way', and are naturally incensed by criticisms" (15). While the Americans and British condescend to join the Samoan "schoolboy entertainment", the Germans resemble irrational adults, with their arbitrary rules of conduct, but also bullying children, sulky and ready to lash out at the slightest provocation. In either case, Stevenson's principal literary purpose in characterising Footnote's Samoan protagonists as children is to establish their distance from the Germans. At one point, he writes that

Foreigners in these islands know little of the course of native intrigue. Partly the Samoans cannot explain, partly they will not tell. Ask how much a master can follow the puerile politics in any school. (133)

Even as Stevenson compares the colonists to "masters", he makes clear that it is the "master" who lacks sufficient insight into the manners of his pupils, not vice versa.

Stevenson's valorisation of rumour and speech is accompanied by a highly sceptical treatment of the Germans' written proclamations and documents. While spoken rumour can mislead and confuse, only writing can suppress. Commenting on a German threat to dynamite Apia's prison should the captured rebels within attempt an escape, Stevenson noted that "you shall look in vain in either Blue Book or White Book [the official records of the Europeans] for any mention even of the charge; it is gone like the conjurer's orange" ("Letters to the Times" 284). From the start of his history, Stevenson contrasts Samoan "etiquette and morals" with the Europeans' impersonal methods of communication and equally impersonal, mechanical methods of warfare: theirs is "the part played in [Footnote] by mails and telegraphs and iron warships" $(F H 1)$. Colonial actions and proclamations are peculiarly disembodied: describing the white settlement at Apia, in which practically all property is signposted to indicate its foreign ownership, Stevenson 
Bogle Petterson 79

remarks that the observer "will think at times that there are more signposts than men to own them" (12). German signposts, in particular, do not refer to any actual state of affairs, and their claim that Mulinuu "is the property of the German firm [. . .] may be rather taken to imply that the claim has been disputed" (11). Germans use language reductively, to label property, define boundaries and issue orders with an air of authority and finality. By contrast with the expansive, indecisive Samoans, their words are typically "few and uncompromising" (36). Stevenson's history critiques German proclamations by expanding upon them in the Samoan manner, treating that which has been "decided" as open for "debate".

Apia's absurd quantity of signposts points to a colonial obsession with property that is generally depicted as infantile and irrational, just like Wiltshire and Case's obsession with copra, and Attwater's obsession with pearls. Readers are introduced to the German firm's copra plantation with the following striking image:

You ride in a German plantation and see no bush, no soul stirring; only acres of empty sward, miles of cocoanut alley: a desert of food. In the eyes of the Samoan the place has the attraction of a park for the holiday schoolboy, of a granary for mice. [. . .] For the Samoan besides, there is something barbaric, unhandsome and absurd in the idea of thus growing food only to send it from the land and sell it. A man at home who should turn all Yorkshire into one wheatfield, and annually burn his harvest on the altar of Mumbo-Jumbo, might impress ourselves not much otherwise. [. . .] At the worst, then, to help oneself from the plantation will seem to a Samoan very like orchard-breaking to the British schoolboy; at the best, it will be thought a gallant Robin-Hoodish readjustment of a public wrong.

By insisting on the Samoan point of view, or a somewhat idealised version of it, Stevenson 
Bogle Petterson 80 portrays the plantation business - that is, the very reason for the colonisation of Samoa as a superstitious and "barbaric" practice. Similarly, the original manager of the German firm, Theodor Weber, is first described as "an artful and commanding character" - yet the Samoan songs in which "his name still lives" depict him in a rather less flattering light:

One, that I have heard, tells of Misi Ueba [Mr Weber] and a biscuit box the suggesting incident being long since forgotten. Another sings plaintively how all things, land and food and property, pass progressively, as by a law of nature, into the hands of Misi Ueba, and soon nothing will be left for Samoans. This is an epitaph the man would have enjoyed. (17)

Weber is thus reduced to the level of a schoolyard bully, stealing and hoarding all the other children's possessions (perhaps even down to the last biscuit in the box), and gaining a cruel sense of satisfaction from the enterprise. At the same time, the Samoan inclination "to help oneself" from the plantations is perfectly natural, especially since "the idea of theft in itself is not very clearly present to these communists" (20-21). Stevenson's primitivism is very much on the side of the childish primitive, and to some extent his view of Samoans resembles Rousseau's notion of man in harmony with nature, uncontaminated by notions of property. Moreover, Stevenson challenges the equation of Samoan childishness with barbarism in the first place by insisting that, for the Samoan, it is the European who is barbaric. As Jolly notes,

The story of the Europeans' town of Apia becomes the story of its 'progressive decivilisation' [Stevenson's phrase]; far from embodying the law of the irresistible 'advance of civilisation' which underwrote the Whig or Darwinian view of imperial history, Stevenson's account of the colonisation of Samoa is a narrative of cultural regression. ("Robert Louis Stevenson and Samoan History" 131)

The absurdity of European property relations also comes across in the disputes 
Bogle Petterson 81 between the three powers over territorial boundaries in the district of Apia. When the German military threatens to engage Mataafa's rebel forces on land owned by the British firm, Stevenson observes that "it gave an impetus to that ridiculous business which might have earned for the whole episode the name of the war of flags", as the rival consuls plant their flags on every bit of land where they conceive to have a claim: "The disease spread, the flags were multiplied, the operations of war became an egg-dance among miniature neutral territories; and though all men took a hand in these proceedings, all men in turn were struck by their absurdity" ( $F H$ 94-95). Stevenson adds that "[t]he multiplication of flags and little neutral territories had, besides, begun to irritate the Samoans" (98), thus casting the latter in the position of justly annoyed onlookers to an immature and superstitious game. The Europeans' obsession with flags is again depicted when the German warship Olga shells and burns the village of Matafangele to avenge the German military defeat at Fangalii:

The shells fell for the most part innocuous; an eyewitness saw children at play beside the flaming houses; not a soul was injured; and the one noteworthy event was the mutilation of Captain Hamilton's flag. In one sense an incident too small to be chronicled, in another this was of historic interest and import. These rags of tattered bunting occasioned the display of a new sentiment in the United States; and the republic of the west, hitherto so apathetic and unwieldy, but already stung by German nonchalance, leaped to its feet for the first time at the news of this fresh insult. (109)

The "historic" operations of empire are shown to be the outcome of "an incident too small to be chronicled", which resembles nothing so much as a petty schoolyard "insult" (the peaceful "children at play" in the background complete the picture). Jolly refers to the "dwarfing perspective of nature's might" in the hurricane episode, which could "reduce European military power to a 'schoolboy's' game" (Stevenson in the Pacific 97). During 
the hurricane, the German warship Adler is "tossed" upon a reef "like a schoolboy's cap upon a shelf; broken like an egg; a thing to dream of" (FH 123). A similar "dwarfing perspective" can be seen in the "war of flags" episode, which symbolises what Stevenson called the "scramble among dollar-hunters" in the islands (19).

The Europeans in Footnote are repeatedly reduced to an infantile, barbaric and superstitious state, especially when they attempt to assert their authority and give orders. Toward the end of the book, Stevenson writes that "in the last twelve months, our European rulers have drawn a picture of themselves, as bearded like the pard, full of strange oaths, and gesticulating like semaphores" as they agitate for war against Mataafa's forces (140). The officials suffer from the same inability to communicate which Stevenson himself experienced in his first encounter with the inhabitants of the Marquesas. In In the South Seas Stevenson describes how his vessel was boarded by

six-foot men in every stage of undress; some in a shirt, some in a loincloth, one in a handkerchief imperfectly adjusted; some, and these the more considerable, tattooed from head to foot in awful patterns; some barbarous and knived; [. . . all talking, and we could not understand one word. [. . . I own I was inspired with sensible repugnance; [. . ] A kind of despair came over me [...] and a kind of rage to think they were beyond the reach of articulate communication, like furred animals, or folk born deaf, or the dwellers of some alien planet. (8-9)

Stevenson hastens to add that his first impressions were "groundless" and that the "impediment of tongues" was easily overcome once he learned a few words in the local language (10). For the Germans in Footnote, however, the situation is somewhat different. Unlike Stevenson, they are unable and unwilling to meaningfully engage with the Samoans - it is the colonists themselves who are thus "beyond the reach of articulate communication". As Jolly notes, the 
image from Shakespeare's As You Like It suggests the loose sense of barbarity as savagery - the white officials are like violent animals, leopards - but also one of the root meanings of a barbarian as one who does not speak a civilised language but mouths meaningless sounds; 'full of strange oaths, and gesticulating like semaphores', the white officials are barbarians who cannot be understood by those, like the Samoans, who speak the civilised language of peace. ("Robert Louis Stevenson and Samoan History" 130)

As Jolly also points out, the whites' inability to communicate with the Samoans is "one example of the motif of regression which recurs throughout Stevenson's history" (130). Moreover, Stevenson's reference to Shakespeare's famous monologue suggests that the civilised whites have regressed to a state of inarticulate barbarism that also resembles infancy. Jaques' oration in As You Like It, which opens with “All the world's a stage, / And all the men and women merely players" (II.vii.139-40), charts a man's life-cycle, from childhood to adulthood and finally old age, but does so without suggesting growth or maturation. A man's "seven ages" - the infant, the schoolboy, the lover, the warrior, the judge, the geriatric and the corpse - are merely "acts" (142) played out on life's stage; there is no sense of progression from one "act" to the next, but merely "exits" and “entrances” (141). The ending of Jaques' monologue emphasises this lack of progression by depicting old age as a return to childhood:

[A man's] big manly voice,

Turning again toward childish treble, pipes

And whistles in his sound. Last scene of all,

That ends this strange eventful history,

Is second childishness and mere oblivion,

Sans teeth, sans eyes, sans taste, sans everything. (161-66) 
The irony of Stevenson's history is that this regression takes place partly because the Germans rely so heavily on written proclamations, the artefacts of a supposedly advanced society, which do not correspond to Samoan realities. Like Herrick and Attwater in The Ebb-Tide, they have imported their own fantastic texts from Europe - this time, duplicitous treaties and laws rather than Virgil's Aeneid - and sought to apply them to a world "on the wrong side of the Roman wall" (FH 1). Stevenson describes the Berlin Act of 1889, which consolidated the Germans' puppet government, as a "literary work" (139) written simply for the benefit of the imperial powers, with no consideration given to how it would be interpreted by Samoans. ${ }^{24}$ He took particular exception to the clause which purported to allow Samoans to elect their own king "according to the laws and customs of Samoa" (135). The latter, Stevenson claimed, were "ignorantly invoked by the draughtsmen of the Berlin act" (138). He criticised the act for "taking a word out of one state of society and applying it to another, of which the writers know less than nothing, and no European knows much" (139). The acts of the European powers, Stevenson implies, are simply childish stories which the officials tell themselves about Samoa. Stevenson demonstrates that because the Germans' laws are written simply to be obeyed and not questioned, they are ineffectual in Samoan society: towards the end of the book, Mataafa "assumes a regal state" (FH 137) while showing every sign of "literal conformity" (139) to the terms of a treaty which excludes him from the kingship. Mataafa makes a farce of the law even as he obeys it: "literal conformity" does not constrain him since the "long, bland, benevolent" (135) imperialist abstractions of the Berlin Act cannot encompass the complexities of Samoan politics.

At one point, Stevenson remarks that "an official is said to have [. . . summed up the qualifications necessary in a Samoan king [as] 'Pourvu qu'il sache signer!'” (Provided he knows how to sign) (131). Stevenson's account of Samoan political life demonstrates

24 In a letter to J. F. Hogan, a British M.P., Stevenson notes that "the infamous protocol - a measure equally of German vanity, English cowardice, and American incuria - had not been and has never yet been translated into the Samoan language" ("Letters to the Times" 300-301). 
that this stance is not merely contemptuous, but profoundly ignorant. Traditionally the "king" has a limited or "imaginary" authority: he "can so sign himself on proclamations, which it does not follow that anyone will heed" (4). While the German officials believe Samoans are "credulous readers" who will "unquestioningly [. . .] obey the authority of the written word" (Smith 208-9), the Samoans refuse to be assimilated into the script produced in Europe on their behalf, and they treat the act of signature as part of an ongoing debate, rather than signifying an end to debate. As Smith writes, "Samoan leadership [. . f fails] to accord the requisite authority to an act of signature, which is rendered instead as a political performance" (208-9). In failing to notice this, it is the Germans themselves who are in fact "credulous readers", believing fatalistically, like Attwater, that all which is written will be fulfilled.

Even on the rare occasions when they speak to Samoans, the Germans do not converse freely, but rather seek compliance with their own script. This act of literal agreement, which to the German officials means so much, is reduced to a farce by Samoans. Stevenson tells how, when the Germans capture and interrogate the wife of a rebel chief allied to Laupepa, the Samoan king who the Germans have turned against,

The wise lady confined herself in answer to a single word. "Is your husband near Apia?" - "Yes." - "Is he far from Apia? - "Yes." - "Is he in the bush with the king?" - "Yes." - "Are he and the king in different places?" "Yes." Whereupon the witness was discharged. ( FH 37)

The German interrogators fail to meaningfully engage "the witness". She responds to their cues, seeming to agree, but her words refer to nothing. Intent on extracting merely useful information, they do not attempt to explain or justify themselves, or to imagine how their conduct might be perceived. The woman's behaviour resembles that of the childish Samoan which Stevenson describes in the second chapter of his history: "As in a child, a considerable intemperance of speech is accompanied by some power of secrecy. News he 
publishes; his thoughts have often to be dug for" (14). Yet the woman's secrecy is declared "wise". By failing to attach any concrete meaning to the word "Yes", she addresses the Germans according to their folly, reductively. Similarly, when Samoans are interrogated following the German military disaster at Fangalii, it is clear that Stevenson sympathises with them for lying: "As for the natives, they were no doubt cross-examined in that hall of terror, the German consulate, where they might be trusted to lie like schoolboys, or (if the reader prefers it) like Samoans" (107-8). From the Samoan point of view, it is perfectly natural and wise to lie when "cross-examined" in a "hall of terror".

The comparison of Samoans to "schoolboys" is perhaps most prevalent in Stevenson's depiction of native warfare. Here again, the essentially positive childishness of the native/primitive society is contrasted with the bullying of the modern German military. For Samoans, warfare is partly a game, a celebration and a rite of passage.

This is plainly no savage war; it has all the punctillio of the barbarian, and all his parade; feasts precede battles, fine dresses and songs decorate and enliven the field; and the young soldier comes to camp burning (on the one hand) to distinguish himself by acts of valour, and (on the other) to display his acquaintance with field etiquette. (5)

In In the South Seas Stevenson also writes enthusiastically about Samoan warfare, comparing it favourably to modern European wars: "We have been so long used in Europe to that dreary business of war on the great scale, trailing epidemics and leaving pestilential corpses in its train, that we have almost forgotten its original, the most healthful, if not the most humane, of all field sports - hedge-warfare" (33). Throughout Footnote, this "original" form of warfare is depicted as "a war of school children" (86), fought by “childish soldiers" (87). According to Steinmetz, Stevenson's implication "that Samoan warriors were actually playing a game [. . .] served to demasculinize them" (308), while Kucich finds that the treatment of Samoan warfare as a game "could seem callous" 
(Kucich 81). In fact, Stevenson's description of the battles in Footnote is shaped by the recognition that, for Samoans, these are domestic affairs, often literally taking place in their own backyards. His description of the battle of Matautu is punctuated by two "incongruous" episodes, suggestive of Samoan family life: Stevenson tells of a "cow [which] grazed all afternoon unhurt" amid volleys of "hostile bullets"; and of his "native friend, Mrs Mary Hamilton, [who] ran out of her house [. . .] in the midst of battle" to discipline an unruly soldier by giving him "a good shaking" ( $F H$ 65). While the battle itself is fought with "delight in sound and smoke and schoolboy cheering", with "unsophisticated ardour", this does not prevent Stevenson from finding it "illustrated with traits of bravery, that would have fitted a Waterloo or a Sedan" (64). Indeed, it is the very lack of military sophistication which, in Stevenson's account, humanizes and valorises the combatants. Roger Robinson has suggested that Footnote can be read as "a precursor of Orwell's Homage to Catalonia" (122). Certainly, Orwell's descriptions of the Spanish civil war have a similar humanizing quality. Like Stevenson, he describes his fellow-combatants as "a mob of eager children" (Orwell 9), who have not received the benefit of modern, rigorous military training and are simply thrust onto the front, where they must learn for themselves how to fire a rifle. Orwell writes: "In the front line my exasperation sometimes reached the pitch of fury. Spaniards are good at many things, but not at making war" (12). Yet he also implies that because they have not endured disciplinarian training, because they are "not real soldiers" (19), their "essential decency; above all, their straightforwardness and generosity" (11) remains intact. Like Orwell, Stevenson seems to have been ambivalent about the Samoans' lack of military discipline. On the one hand Mataafa's soldiers often neglect to press their advantage. In one battle, having occupied a Tamasese trench, Mataafa's men “instead of completing fresh defences or pursuing their advantage, fell to eat and smoke and celebrate their victory with impromptu songs". This neglect costs them dearly, as they are repelled by "a rally of Tamaseses" (FH 90). On the other hand, as 
Robert Kiely puts it, such a conflict, "[u]nlike the large mechanical wars of the nineteenth century, [. . .] elevates and enhances personality rather than obliterating it" (232). Following the battle of Matautu, Stevenson describes how "the older folk trailed back into Apia in the rain; [talking] as they went of who had fallen and what heads had been taken upon either side - they seemed to know by name the losses upon both" ( $F H$ 66). Such statements, which almost make the reader forget that Stevenson did not in fact witness the battle, belie claims that his treatment of Samoan warfare is belittling. ${ }^{25}$

By contrast, the German officials' method of warfare is depicted as impersonal and aloof, as well as frenzied and destructive. The "unpalatable customs" which "deface" Samoan warfare - such as the "childish destruction of fruit trees in an enemy's country", and even "the habit of head hunting" ( $F H$ 5) - are relatively harmless compared with the shelling of villages "on very trifling grounds by Germans" (19). In general, Europeans conduct their wars from within their "colossal ships, worked by mysterious powers and laden with outlandish instruments of death" (73), and are thus disengaged from Samoa Stevenson writes that an observer "may calculate that there are more whites afloat in Apia Bay than whites ashore in the whole Archipelago" (12). The German military does not share in the "unsophisticated", but human, chaos of Samoan battles. Of the destruction of one rebellious village, Stevenson sarcastically writes that it was "burned by German sailors, in a very decent and orderly style, on the 3rd September" (35). Smith observes that the characters in Footnote are "implicitly [. . .] measured by the index of representation. They either testify to the author's ability to bring them back to life, or resist animation, remaining stubbornly text-bound" (207). Stevenson's descriptions of the shelling of villages contrast life-like Samoans with detached, "mysterious" foreigners, firing from within their floating iron vessels. During the battle at Fangalii, for instance, the Eber

25 This paragraph develops observations on Stevenson's depiction of Samoan warfare which were first made in my unpublished essay “The Literary Authority of Stevenson's A Footnote to History” (Bogle Petterson 2008, 4-5), written for Professor Roger Robinson's Honours course, "Journalism and Literature", at Victoria University of Wellington. 
"threw some shells into Letongo, one of which killed five men about their cooking-pot" (102). On another occasion, "three shells were thrown inland at Mangiangi; they flew high over the Mataafa camp, where the natives could 'hear them singing' as they flew, and fell behind in the deep romantic valley of the Vaisingano" (110). One might compare these descriptions with the scene in Heart of Darkness where Marlowe witnesses

a man-of-war anchored off the coast [of Africa ... .] shelling the bush. [. . .] In the empty immensity of earth, sky, and water, there she was, incomprehensible, firing into a continent. [. . .] There was a touch of insanity in the proceeding, a sense of lugubrious drollery in the sight; and it was not dissipated by someone on board assuring me earnestly there was a camp of natives - he called them, enemies - hidden out of sight somewhere.

In Marlowe's narrative the warship appears to be firing into an impersonal "continent" populated by anonymous "enemies", and this gives the "proceeding" its "touch of insanity". The details of Samoan domestic life provided by Stevenson counter this perspective. In Footnote, it is the invisibility of the Europeans, their absence from the scene of battle, their impersonality, which renders the shelling an incongruous, almost surreal intrusion. The Samoan landscape seems to reduce the German shells, transforming them into harmless birds.

The German warships serve the same function as the metaphorical "diving-dress of self-conceit" in The Ebb-Tide (229), namely, to enable the colonisers " "to go down into the world [. . .], and come up scatheless"” (202), to cocoon them from any new experiences. Their advanced technology does not "elevate" them, but rather dwarfs them, keeping them in a state of underdevelopment. Thus cut off, literally and figuratively separated from Samoan life, the Germans, like Attwater, do not see their victims as human. In one of his letters to the Times, Stevenson describes a discussion with one of the European consuls (he 
Bogle Petterson 90

does not say which one) who had recently returned from visiting the island of Manono, where the puppet government's troops had just destroyed a rebel village. Stevenson asked if there had not been some houses burned. He told me no. I repeated the question, alleging the evidence of officers on board the Katoomba who had seen the flames increase and multiply as they steamed away; whereupon he had this remarkable reply - “O, huts, huts, huts! There isn't a house, a frame house, on the island." ("Letters to the Times" 287-8)

The consul's "ejaculation" (288) reduces the Samoan villages to the status of toys; their "huts" can be destroyed with no undue concern. Footnote's portrayal of colonial officials as themselves reduced by their reliance on modern machinery of war can be seen as a kind of literary revenge for such statements, which Stevenson found repulsive.

Despite their apparent military superiority, Stevenson notes a lack of harmony between the Germans' forceful, threatening despatches and the tendency of their military acts to "fizzle" (FH 97). He describes the German official Brandeis' letter threatening to burn the island of Manono, followed by the shelling itself, and observes: "The letter had been energetic; the performance fell below the programme" (57). Knappe later commits the same blunder, writing a "threatening despatch" urging Mataafa to remove his troops from Laulii or else "Knappe would turn upon him 'the attention of the man-of-war' and inflict a fine" (93). But this threat also turns out to be a relatively empty one as, in the end, Knappe "contented himself with visiting the rival kings" (94). Unless the colonists succeed in forcibly altering Samoa's political landscape, Stevenson implies, their imperious declarations are meaningless. He writes of one official:

It was not wise in the president to proclaim Mataafa and his followers rebels and their estates confiscated. Such words are not respectable till they repose on force; on the lips of an angry white man, standing alone on a small promontory, they were both dangerous and absurd. (140) 
Imperial proclamations are again and again reduced to "absurd" bullying taunts, delivered by individuals "standing alone", isolated from Samoan society. For Stevenson, such threats are no less "dangerous" for being merely rhetorical, because the Germans endanger themselves by coming to believe in the substance of their own rhetoric, very much like the white men in "The Isle of Voices" who are "like children and only believe their own stories" (112). He attributes the German military defeat and heavy loss of life at Fangalii to one such rhetorical outburst, "a letter from Brandeis to Knappe - 'Brandeis' inflammatory letter', Bismark calls it" ( FH 69). In pointing out that the Germans do not have the military strength to support such trenchant despatches, Stevenson does not advocate intensified repression. Rather, he demonstrates that the rhetoric of imperialism possesses no innate authority and that the Germans, like all bullies, are capable of enforcing their rule only by violently imposing it. ${ }^{26}$

At the same time as Footnote undermines the authority of white officials in Samoan society by portraying them as inflexible, detached and "unteachable", it also charts the growth of Samoans, and particularly their shedding of "superstitious" fears of the Great Powers. In this regard, the Germans' defeat at Fangalii is a pivotal episode. After the battle, all Samoa drew a breath of wonder and delight. The invincible had fallen; the men of the vaunted warships had been met in the field by the braves of Mataafa: a superstition was no more. Conceive this people steadily as schoolboys; and conceive the elation of any school if the head boy should suddenly rise and drive the rector from the schoolhouse. (105)

As Jolly writes, the German defeat at Fangalii did not only end this Samoan "superstition": "From a European perspective the significance of Fangalii was that it showed the Samoans could win a contest with a more advanced nation, and this challenged a 'superstition' of their own - that history always demonstrates the triumph of progressive civilization over 
traditional societies" (Stevenson in the Pacific 96). The Europeans in Footnote refuse to learn from their defeats and are therefore kicked out of school - by the "schoolboys" themselves, no less. If anything, Stevenson's picture of Mataafa's ascendancy as 'king - or not-king - or king-claimant" (150) and of the collapse of German authority - "the German adventure in Samoa was defeated", he states at one point (51) - is overdrawn, a combination of poetic licence and what Kucich calls "wishful thinking" (73). As Malama Meleisea points out, Stevenson's “activism was in vain. Mata'afa's cause was lost [. . and] in 1899 the three powers partitioned the Samoan archipelago between Germany and the United States of America" ( $F H$ xv-xvi). Stevenson's fear that the islands' fate would be decided by "[f]oreign ships and bayonets" (154) was realised. Nevertheless, the depiction of Samoans not simply as passive victims of imperialism but as actively struggling for independence and spurred on by their taste of victory is a remarkable counterpoint to the pessimism of The Ebb-Tide. 


\section{Conclusion}

Bogle Petterson 93

What compelled Stevenson to become such a clear-sighted opponent of imperialism in the Pacific? This question has been posed by a number of critics over the past two decades, during which time Stevenson's late works have been rediscovered after decades of critical neglect. John Kucich, for instance, emphasises the importance of these works by arguing for 'the improbability of Stevenson's moral and psychological conversion to antiimperialist causes in the first place" (85). Kucich contends that Stevenson made an "abrupt political transition" (82) by channelling "the moral and psychological authority previously identified with evangelical middle-class culture into an anti-imperialist crusade" (84). According to Kucich, Stevenson's anti-imperialism is characterised by "its political fluidity", "is always in danger of sliding back into jingoism" and even "threaten[s] to merge" with the imperialist views of Kipling and Haggard (82). Yet, as this thesis has shown, Stevenson's opposition to the colonisation of the Pacific was not in fact such an improbable or "abrupt" transition. His sympathy for the victims of colonisation is clearly on display in Kidnapped, which, taken together with Catriona, Barry Menikoff correctly identifies as "an anticolonialist document" (Narrating Scotland 205). Moreover, Stevenson's late writings frequently compare Pacific islanders to Highlanders, and it is clear that he saw both as the victims of foreign oppression. He thus warned a gathering of Samoan chiefs that if they did not "occupy and use" their islands, they would suffer the same fate as those who were cleared off the Highlands to make room for sheep farms (“Address to the Samoan Chiefs, Vailima" 122-3).

In tracing Stevenson's use of a particularly pervasive trope, the primitive-as-child, I have sought to illuminate the continuity as well as the development of Stevenson's antiimperialism. The works I have examined each dramatise the clash between "primitive" and 
Bogle Petterson 94

"civilised" societies, in which the former is generally associated with childishness. As we have seen, this association does not belittle but rather elevates the youthful primitives above the decrepit moderns. The childish features of Stevenson's Highlanders and Pacific islanders, including their lack of discipline, their spontaneous creativity, their rebellious nature, and their orality and illiteracy, are all valorised so that "civilised" characters like David Balfour and John Wiltshire are endeared to the reader only to the extent that they come to share these features and drop their claims to maturity.

At the same time, Stevenson's works reveal the maturity of civilised society to be little more than a hollow sham. Kidnapped's hostility toward adult detachment and complacency develops, in the Pacific works, into an outright rejection of "civilised" authority. The representatives of colonisation in The Ebb-Tide, "The Beach of Falesá" and A Footnote to History are themselves depicted as selfish, bullying children, introducing barbarism and decay into the Pacific, even as they assert their authority over the natives.

There are, of course, definite short-comings in Stevenson's anti-imperialism, which can be seen in his use of the child trope; a residual paternalism toward "primitive" peoples can be found even his most radical works. Stevenson's best writing, as we have seen, works against this paternalism by emphasising the infantilism of imperialism itself. Yet this strategy is not entirely unproblematic: underlying the critique of imperialism in the Pacific works, some critics have detected a yearning for a return to patriarchal, feudal authority. Christopher Harvie contends that "Stevenson's political creed is authoritarian but - unlike Kipling - feudal and familial rather than technocratic". He suggests that, in Samoa, Stevenson "tried to recreate [. . .] a charismatic authority now being sapped by imperialist bureaucrats as much as by socialistic bureaucrats at home" (124). But Harvie overstates the case: as we have seen, part of what attracted Stevenson to traditional Samoan society was the apparent absence of authority. He was repelled by imperialism because it sought to brutally impose authority where none was called for. 
Critics like Kucich and Harvie begin with the premise that Stevenson's early works are essentially conservative and then seek to explain, in one way or another, how he adapted this conservative ethos in order to become an advocate of Samoan independence. A basic premise of this thesis has been that Stevenson's artistic response to imperialism was determined, first and foremost, by profound sympathy for its victims and scathing hostility toward its perpetrators. Spurred by these sentiments, Stevenson was able to overcome, to a remarkable extent, the colonial rhetoric and mythology of his time including the myth of racial superiority - and indeed was able to depict this mythology as mere children's fairy tales. The best writing, contrary to the claims of Edward Said, Bill Ashcroft and other theorists, is not constrained or censored by language, but is able to reshape it and give it new meaning. As we have seen, Stevenson's works encourage a return to speech, that is, to what he saw as the primitive and formative state of language, in which hardened clichés are broken down. The richness of meaning that can be found in Stevenson's use of a single trope should remind us to be wary of sweeping claims about the awful power of colonial discourse. 


\section{Texts Cited}

Acheraïou, Amar. Rethinking Postcolonialism: Colonialism in Modern Literatures and the Legacy of Classical Writers. Basingstoke: Palgrave Macmillan, 2008.

Ahmad, Aijaz. In Theory: Classes, Nations, Literatures. $2^{\text {nd }}$ ed. London: Verso, 2008. 159 220.

Arnold, Thomas. Thomas Arnold on Education. Ed. T. W. Bamford. Cambridge: Cambridge University Press, 1970.

Ashcroft, Bill. On Post-Colonial Futures: Transformations of Colonial Culture. London: Continuum, 2001.

Berlin, Isaiah. Freedom and its Betrayal: Six Enemies of Human Liberty. Ed. Henry Hardy. Princeton: Princeton University Press, 2002.

Boas, George. The Cult of Childhood. London: Warburg Institute, 1966.

Bogle Petterson, Thomas. "The Literary Authority of Stevenson's A Footnote to History". Unpublished essay for ENGL 439: Journalism and Literature. Course Coordinator: Professor Roger Robinson. Victoria University of Wellington, 2008.

Brantlinger, Patrick. Rule of Darkness: British Literature and Imperialism, 1830-1914. Ithaca: Cornell University Press, 1988.

--- "Heart of Darkness: Anti-Imperialism, Racism or Impressionism?" In Fictions of Empire. Ed. John Kucich. Boston: Houghton Mifflin Co., 2003. 385-404.

Bristow, Joseph. Empire Boys: Adventures in a Man's World. London: Unwin Hyman, 1991.

Buckton, Oliver S. Cruising with Robert Louis Stevenson: Travel, Narrative and the Colonial Body. Ohio: Ohio University Press, 2007.

Calinescu, Matei. Five Faces of Modernity: Modernism, Avant-Garde, Decadence, Kitsch, Postmodernism. Durham: Duke University Press, 1987.

Césaire, Aimé. Discourse on Colonialism. Trans. Joan Pinkham. New York: Monthly Review Books, 1972.

Chesterton, G. K.. Robert Louis Stevenson. London: Hodder and Stoughton, 1927.

Colley, Ann C. Robert Louis Stevenson and the Colonial Imagination. Hampshire: Ashgate Publishing Ltd., 2004.

Conrad, Joseph. Heart of Darkness. 1899. Ed. Robert Kimbrough, $3^{\text {rd }}$ ed. New York: W. W. Norton \& Company Inc., 1988. 
Coveney, Peter. The Image of Childhood: The Individual and Society. A Study of the Theme in English Literature. Harmondsworth: Penguin, 1967.

Cunningham, Hugh. Children of the Poor: Representations of Childhood Since the Seventeenth Century. Oxford: Blackwell, 1991.

Daiches, David. Robert Louis Stevenson. Glasgow: MacLellan, 1947.

Diderot, Denis. Supplément au Voyage de Bougainville. 1770. Political Writings. Eds. John Hope Mason and Robert Wokler. Cambridge: Cambridge University Press, 1992. 31-76.

Edmond, Rod. Representing the South Pacific: Colonial Discourse from Cook to Gauguin. Cambridge: Cambridge University Press, 1997.

Eigner, Edwin M. Robert Louis Stevenson and Romantic Tradition. Princeton: Princeton University Press, 1966.

Emerson, Ralph Waldo. "Nature". 1836. The Portable Emerson. Eds. Carl Bode and Malcolm Cowley. Middlesex: Viking Penguin Inc., 1981. 7-50.

--- "Self-Reliance". 1841. The Portable Emerson. Eds. Carl Bode and Malcolm Cowley. Middlesex: Viking Penguin Inc., 1981. 138-164.

Fanon, Frantz. Black Skin, White Masks. 1952. Trans. Richard Philcox. New York: Grove Press, 2008.

Fielding, Penny. Writing and Orality: Nationality, Culture and Nineteenth-Century Scottish Fiction. Oxford: Oxford University Press, 1996.

Gay, Peter. The Enlightenment: An Interpretation. Vol. 2: The Science of Freedom. London: $\quad$ Weidenfeld and Nicholson, 1969.

“Gewgaw.” Def. 1a. The Oxford English Dictionary. 2nd ed. 1989.

Gilmour, Peter. "Robert Louis Stevenson: Forms of Evasion". In Robert Louis Stevenson. Ed. Andrew Noble. London: Vision Press, 1983. 188-201.

Gould, Stephen Jay. Ontogeny and Phylogeny. Cambridge, Mass.: Belknap Press of Harvard University Press, 1977.

Grylls, David. Guardians and Angels: Parents and Children in Nineteenth-Century Literature. London: Faber and Faber, 1978.

Haggard, H. Rider. King Solomon's Mines. 1885. Hertfordshire: Wordsworth Editions Ltd., 1993.

Harvie, Christopher. "The Politics of Stevenson". Stevenson and Victorian Scotland. Ed. Jenni Calder. Edinburgh: Edinburgh University Press, 1981. 107-125.

Hayes, Timothy S. 'Colonialism in R. L. Stevenson's South Seas Fiction: 'Child's Play' in the Pacific”. English Literature in Transition, 1880-1920. 52.2 (2009): 160-181. 
Hillier, Robert I. The South Seas Fiction of Robert Louis Stevenson. New York: Peter Lang, 1989.

Holt, John. "Schools Are Bad Places for Kids". The Underachieving School by John Holt. Middlesex: Penguin Books, 1971. 22-36.

Jackson, David H. “Treasure Island as a Late-Victorian Adults' Novel”. The Victorian Newsletter. 72 (1987): 28-32.

James, Henry. "Robert Louis Stevenson". 1888. Henry James and Robert Louis Stevenson: A Record of Friendship and Criticism. Ed. Janet Adam Smith. Westport, Conn.: Hyperion Press, 1979. 123-160.

Jolly, Roslyn. "The Ebb-Tide and The Coral Island". Scottish Studies Review 7.2 (2006): 79-91.

--- "Introduction" and "Notes". South Sea Tales by Robert Louis Stevenson. Ed. Roslyn Jolly. Oxford: Oxford University Press, 1996. ix-xxxiii and 259-289.

--- Robert Louis Stevenson in the Pacific: Travel, Empire and the Author's Profession. Aldershot: Ashgate, 2009.

--- "Robert Louis Stevenson and Samoan History: Crossing the Roman Wall". Fictions of Empire. Ed. John Kucich. Boston: Houghton Mifflin Co., 2003. 126-133.

Kiely, Robert. Robert Louis Stevenson and the Fiction of Adventure. Cambridge, Mass.: Harvard University Press, 1964.

Kipling, Rudyard. "Tods' Amendment". Plain Tales from the Hills. 1888. Ed. Andrew Rutherford. Oxford: Oxford University Press, 2001. 144-49

--- “The White Man's Burden”. 1903. Fictions of Empire. Ed. John Kucich. Boston: Houghton Mifflin Co., 2003. 326-7.

Kucich, John. Imperial Masochism: British Fiction, Fantasy and Social Class. Princeton: Princeton University Press, 2007.

Lenin, V. I. Imperialism, the Highest Stage of Capitalism. 1916. Moscow: Progress Publishers, 1983.

Linehan, Katherine. “Taking Up with Kanakas: Stevenson's Complex Social Criticism in "The Beach of Falesá"”. Fictions of Empire. Ed. John Kucich. Boston: Houghton Mifflin Co., 2003. 359-73.

Luxemburg, Rosa. The Junius Pamphlet: The Crisis in German Social Democracy February-April 1915. In The Mass Strike, The Political Party and the Trade Unions and The Junius Pamphlet. Ed. Robert Bland. 97-222. New York: Harper and Row Publishers, 1971.

Maixner, Paul. Robert Louis Stevenson, the Critical Heritage. London: Routledge and Kegan Paul, 1981. 
Meleisea, Malama. "Introduction". A Footnote to History: Eight Years of Trouble in Samoa by Robert Louis Stevenson. Ed. Malama Meleisea. Auckland: Pasifika Press, 1996. vii-xvi.

Menikoff, Barry. Narrating Scotland: the Imagination of Robert Louis Stevenson. Columbia, South Carolina: University of South Carolina Press, 2005.

--- "Introduction". Kidnapped, or, The Lad with the Silver Button: the Original Text. California: Huntington Library Press, 1999.

--- "A Study in Victorian Publishing". In Robert Louis Stevenson and 'The Beach of Falesá': A Study in Victorian Publishing with the Original Text. Ed. Barry Menikoff. Stanford: Stanford University Press, 1984. 3-109.

Najita, Susan Y. Decolonizing Cultures in the Pacific: Reading History and Trauma in Contemporary Fiction. New York: Routledge, 2006.

Orwell, George. Homage to Catalonia. 1938. London: Penguin, 2003.

Phillips, Lawrence. "Colonial Culture in the Pacific, in Robert Louis Stevenson and Jack London". Race and Class. 48.3 (2007): 63-82.

Plekhanov, G. V. Fundamental Problems of Marxism. 1908. Moscow: Progress Publishers, 1977.

Reid, Julia. Robert Louis Stevenson, Science, and the Fin de Siècle. Basingstoke: Palgrave Macmillan, 2006.

Robinson, Roger. "Commentaries". Robert Louis Stevenson: His Best Pacific Writings by Robert Louis Stevenson. Ed. Roger Robinson. Auckland: Streamline Creative Limited, 2003.

Robson, W. W. “On Kidnapped”. Stevenson and Victorian Scotland. Ed. Jenni Calder. Edinburgh: Edinburgh University Press, 1981. 88-106.

Rollin, Lucy. "Through A Child's Garden Toward a Neurological Aesthetic of Children's Literature". Children's Literature Association Quarterly 27.2 (2002): 71-76.

Rose, Jacqueline. The Case of Peter Pan: Or, The Impossibility of Children's Fiction. 2nd ed. Basingstoke: Macmillan, 1994.

Rosen, Michael. "Robert Louis Stevenson and Children's Play: The Contexts of A Child's Garden of Verses". Children's Literature in Education 26.1 (1995): 53-72.

Rousseau, Jean-Jacques. Discourse on the Origin of Inequality. 1755. In The Basic Political Writings. Trans. Donald A. Cress. Indiana: Hackett Publishing Company Inc., 1987.

--- Emile. 1762. Trans. Barbara Foxley. London: J. M. Dent and Sons Ltd., 1974.

Said, Edward. Orientalism. London: Penguin Books, 2003. 
Sandison, Alan. Robert Louis Stevenson and the Appearance of Modernism: A Future Feeling. London: Macmillan, 1996.

Saposnik, Irving S. Robert Louis Stevenson. New York: Twayne Publishers, 1974.

Shakespeare, William. As You Like It.c. 1623. The Complete Works of William Shakespeare. Ed. W. J. Craig. London: Oxford University Press, 1913. 249-278.

Shapiro, Stephen. "Mass African Suicide and the Rise of Euro-American Sentimentalism: Equiano's and Stevenson's Tales of the Semi-Periphery". In Revolutions and Watersheds: Transatlantic Dialogues, 1775-1815. Eds. Wil Verhoeven and Beth Dolan Kurtz. Amsterdam: Rodopi, 1999. 123-144.

Smith, Vanessa. Literary Culture and the Pacific: Nineteenth-Century Textual Encounters. Cambridge: Cambridge University Press, 1998.

Steinmetz, George. The Devil's Handwriting: Precoloniality and the German Colonial State in Qingdao, Samoa and Southwest Africa. Chicago: University of Chicago Press, 2007.

Stevenson, Robert Louis. "Address to Samoan Chiefs, Vailima”. 1890. In Sophia Scarlet and Other Pacific Writings. Ed. Robert Hoskins. Auckland: AUT Media, 2008. 121-125.

--- "Address to Samoan Students, Malua". 1890. In Sophia Scarlet and Other Pacific Writings. Ed. Robert Hoskins. Auckland: AUT Media, 2008. 69-77.

--- "The Beach of Falesá". 1893. In Robert Louis Stevenson and 'The Beach of Falesá': A Study in Victorian Publishing with the Original Text. Ed. Barry Menikoff. Stanford: Stanford University Press, 1984. 113-188.

--- "The Bottle Imp". 1891. In South Sea Tales. Ed. Roslyn Jolly. Oxford: Oxford University Press, 1996. 72-102.

--- Catriona. 1893. The Works of Robert Louis Stevenson, Tusitala Edition. Vol. 7. London: William Heinemann Ltd., 1924.

--- "The Character of Dogs". 1884. The Works of Robert Louis Stevenson, Tusitala Edition. Vol. 29. London: William Heinemann Ltd., 1924. 93-102.

--- “Child's Play”. 1878. The Works of Robert Louis Stevenson, Tusitala Edition. Vol. 25. London: William Heinemann Ltd., 1924. 106-116.

--- “Debating Societies". 1871. The Works of Robert Louis Stevenson, Tusitala Edition. Vol.

25. London: William Heinemann Ltd., 1924. 148-153.

--- The Ebb-Tide. 1894. In South Sea Tales. Ed. Roslyn Jolly. Oxford: Oxford University Press, 1996. 123-252.

--- “The Education of an Engineer". 1888. The Works of Robert Louis Stevenson, Tusitala 
Edition. Vol. 30. London: William Heinemann Ltd., 1924. 20-28.

--- "Father Damien: An Open Letter to the Reverend Dr. Hyde of Honolulu". 1890. The Works of Robert Louis Stevenson, Tusitala Edition. Vol. 21. London: William Heinemann Ltd., 1924. 25-42.

--- A Footnote to History: Eight Years of Trouble in Samoa. 1892. Ed. Malama Meleisea. Auckland: Pasifika Press, 1996.

--- “A Humble Remonstrance”. 1884. The Works of Robert Louis Stevenson, Tusitala Edition. Vol. 29. London: William Heinemann Ltd., 1924. 132-143.

--- In the South Seas. 1896. Ed. Neil Rennie. London: Penguin, 1998.

--- "The Isle of Voices". 1893. In South Sea Tales. Ed. Roslyn Jolly. Oxford: Oxford University Press, 1996. 103-122.

--- Kidnapped. 1886. Ed. Donald McFarlan. London: Penguin, 1994.

--- The Letters of Robert Louis Stevenson. Eds. Bradford A. Booth and Ernest Mehew. New Haven: Yale University Press, 1994.

--- "Letters to the Times, Athenaeum, Pall Mall Gazette, etc." The Works of Robert Louis Stevenson, Tusitala Edition. Vol. 21. London: William Heinemann Ltd., 1924. 241304.

--- "My Treasures". A Child's Garden of Verses. 1885. New York: Dover Publications Inc., 1992. 54.

--- "Notes on the Movements of Young Children". 1874. The Works of Robert Louis Stevenson, Tusitala Edition. Vol. 25. London: William Heinemann Ltd., 1924. 196201.

--- "Talk and Talkers" (Parts 1 and 2). 1882. The Works of Robert Louis Stevenson, Tusitala Edition. Vol. 29. London: William Heinemann Ltd., 1924. 71-92

--- Travels with a Donkey in the Cevennes. 1879. In The Works of Robert Louis Stevenson, Tusitala Edition. Vol. 17. London: William Heinemann Ltd., 1924. 127-253.

--- Treasure Island. 1883. Ed. John Seelye. London: Penguin, 1999.

--- Vailima Letters. Ed. Sidney Colvin. 1895. 18th edition. London: Methuen, 1920.

--- "Walt Whitman". 1878. Familiar Studies of Men and Books. United Kingdom: T. Nelson and Sons, Ltd., n. d.

Thorburn, David. Conrad's Romanticism. New Haven: Yale University Press, 1974.

Treglown, Jeremy. "Out of the Diving Suit: Robert Louis Stevenson". Grand Street. 6.1 (1986): 122-140.

Wilde, Oscar. "The Soul of Man Under Socialism". 1891. The Soul of Man Under 
Socialism and Selected Critical Prose. Ed. Linda Dowling. London: Penguin, 2001. 125-160.

Womack, Peter. Improvement and Romance: Constructing the Myth of the Highlands. Basingstoke: Macmillan, 1989.

Wordsworth, William. "My heart leaps when I behold". 1802. English Romantic Poetry: An Anthology. Ed. Stanley Appelbaum. Mineola, New York: 1996. 35. 